\title{
Characterizing the surface microlayer in the Mediterranean Sea: trace metal concentrations and microbial plankton abundance
}

\author{
Antonio Tovar-Sánchez ${ }^{1}$, Araceli Rodríguez-Romero ${ }^{1}$, Anja Engel $^{2}$, Birthe Zäncker $^{2}$, Franck Fu ${ }^{3}$, Emilio Marañón ${ }^{4}$, \\ María Pérez-Lorenzo ${ }^{4}$, Matthieu Bressac ${ }^{5,6}$, ${\text { Thibaut } \text { Wagener }^{7} \text {, Sylvain } \text { Triquet }^{3} \text {, Guillaume Siour }}^{3}$, \\ Karine Desboeufs ${ }^{3}$, and Cécile Guieu ${ }^{6}$ \\ ${ }^{1}$ Department of Ecology and Coastal Management, Institute of Marine Sciences of Andalusia (ICMAN-CSIC), \\ 07190 Puerto Real, Spain \\ ${ }^{2}$ Helmholtz Centre for Ocean Research (GEOMAR), Kiel, Germany \\ ${ }^{3}$ Laboratoire Interuniversitaire des Systèmes Atmosphériques (LISA), CNRS UMR 7583, \\ Université de Paris, Université Paris-Est-Créteil, Institut Pierre Simon Laplace (IPSL), Créteil, 94000, France \\ ${ }^{4}$ Departamento de Ecología y Biología Animal, Universidad de Vigo, 36310 Vigo, Spain \\ ${ }^{5}$ Institute for Marine and Antarctic Studies, University of Tasmania, Hobart, Tasmania, Australia \\ ${ }^{6}$ Sorbonne Université, CNRS, Laboratoire d'Océanographie de Villefranche, LOV, Villefranche-sur-mer, 06230, France \\ ${ }^{7}$ Aix Marseille Univ., CNRS, IRD, Université de Toulon, MIO UMR 110, Marseille, 13288, France
}

Correspondence: Antonio Tovar-Sánchez (a.tovar@csic.es)

Received: 25 July 2019 - Discussion started: 31 July 2019

Revised: 8 March 2020 - Accepted: 30 March 2020 - Published: 30 April 2020

\begin{abstract}
The Sea Surface Microlayer (SML) is known to be enriched by trace metals relative to the underlying water and harbor diverse microbial communities (i.e., neuston). However, the processes linking metals and biota in the SML are not yet fully understood. The metal $(\mathrm{Cd}, \mathrm{Co}, \mathrm{Cu}, \mathrm{Fe}, \mathrm{Ni}$, $\mathrm{Mo}, \mathrm{V}, \mathrm{Zn}$ and $\mathrm{Pb}$ ) concentrations in aerosol samples in the SML (dissolved and total fractions) and in subsurface waters (SSWs; dissolved fraction at $\sim 1 \mathrm{~m}$ depth) from the western Mediterranean Sea were analyzed in this study during a cruise in May-June 2017. The composition and abundance of the bacterial community in the SML and SSW, the primary production, and Chl $a$ in the SSW were measured simultaneously at all stations during the cruise. Residence times in the SML of metals derived from aerosol depositions were highly variable and ranged from minutes for $\mathrm{Fe}(3.6 \pm 6.0 \mathrm{~min})$ to a few hours for $\mathrm{Cu}(5.8 \pm 6.2 \mathrm{~h})$. Concentrations of most of the dissolved metals in both the SML and SSW were positively correlated with the salinity gradient and showed the characteristic eastward increase in the surface waters of the Mediterranean Sea (MS). In contrast, the total fraction of some reactive metals in the $\mathrm{SML}$ (i.e., $\mathrm{Cu}, \mathrm{Fe}, \mathrm{Pb}$ and $\mathrm{Zn}$ ) showed a negative correlation with salinity and a positive correlation with microbial abundance, which might be as-
\end{abstract}

sociated with microbial uptake. Our results show a strong negative correlation between the dissolved and total $\mathrm{Ni}$ concentration and heterotrophic bacterial abundance in the SML and SSW, but we cannot ascertain whether this correlation reflects a toxicity effect or is the result of some other process.

\section{Introduction}

The Mediterranean Sea (MS) is enriched in many trace metals relative to similar nutrient-depleted waters in the open ocean (e.g., Cd, Cr, Co, Cu, Ni, Fe, Zn) (Bonnet et al., 2013; Boyle et al., 1985; Sarthou and Jeandel, 2001; Sherrell and Boyle, 1988). The enrichment of metals in surface water has been associated with different sources, including atmospheric deposition, river inflows, groundwater supply, anthropogenic sources and the Atlantic Ocean inflow through the Strait of Gibraltar (Boyle et al., 1985; Elbaz-Poulichet et al., 2001; Migon, 2005; Trezzi et al., 2016). The MS has one of the highest rates of aeolian deposition in the world with strong pulses of mineral dust from Africa, in addition to regular anthropogenic aerosol inputs from Europe. Therefore, 
atmospheric deposition, both dry and wet, is the dominant pathway for the large-scale transport of trace metals to the water column and sediments in the MS (Guieu et al., 2002, 2010; Jordi et al., 2012; Ternon et al., 2010; Tovar-Sánchez et al., 2010, 2014). Many of these metals play an important role in biogeochemical processes of this sea. For example, it has been hypothesized that the high Co concentrations in the MS may stimulate "de novo" synthesis of vitamin $\mathrm{B}_{12}$ as $\mathrm{Co}$ is the central metal ion in the $\mathrm{B}_{12}$ molecule (Bonnet et al., 2013). Although present in a higher concentration than in other oceans, Fe may control phytoplankton growth and composition (Sarthou and Jeandel, 2001). Copper from aerosol deposition has been demonstrated to have toxic effects on marine phytoplankton (Jordi et al., 2012; Paytan et al., 2009), while Ni and $\mathrm{Zn}$ concentrations in Posidonia oceanica are considered good proxy for aerosol deposition (Tovar-Sánchez et al., 2010).

The Sea Surface Microlayer (SML) is considered the skin of the ocean, as it serves as a boundary layer between the atmosphere and the ocean. With a thickness of $1-1000 \mu \mathrm{m}$, it is a prevalent feature of the oceans' surface that shows distinct physical, chemical, and biological properties. This sea-air interface plays a key role in regulating the exchange of gases, solutes and energy between water and the atmosphere and is central to a wide range of global biogeochemical and climate regulation processes (Cunliffe et al., 2013). Characterized by a high abundance of microorganisms (called neuston and ranging from bacteria to larger siphonophores; Wurl et al., 2017), the SML constitutes a particular marine ecosystem. Neuston in the SML is sustained by recruitment from the underlying plankton, but its composition and activities are different as they are heavily conditioned by meteorological conditions, intensity of UV radiation, organic matter content and/or aerosol impact, among others (Cunliffe et al., 2013; Engel et al., 2017).

Impacted by different allochthonous sources (e.g., aerosols, ice, rivers) the SML is enriched in reactive trace metals (e.g., $\mathrm{Cu}, \mathrm{Fe}, \mathrm{Pb}$ ) whose metal stoichiometry signature is different from that of the underlying waters (TovarSánchez et al., 2019). For example, in regions under the influence of dust events, such as the North Atlantic Ocean or Mediterranean Sea, concentrations of $\mathrm{Cu}, \mathrm{Fe}$ or $\mathrm{Pb}$ in the total pool of the SML are up to 800, 200 and 150 times higher than in the dissolved metal pool of the underlying water (TovarSánchez et al., 2019). However, despite such enrichment in the concentration of trace metals, little is known about their residence times, their influence on the activity of the microbial community within the SML, or their impact on the biogeochemistry of the underlying waters. Previous studies, using data from both field sampling and laboratory microcosms, have estimated the residence times of dissolved and particulate trace metals (e.g., $\mathrm{Al}, \mathrm{Fe}, \mathrm{Mn}, \mathrm{Ni}, \mathrm{Cu}, \mathrm{Zn}$, and $\mathrm{Pb}$ ) in the SML to range from a few minutes to a few hours. This is likely long enough to alter the SML chemically and biologically and affect the composition and activity of the neuston community (Ebling and Landing, 2017; Hardy et al., 1985). However, there is still a lack of estimates of residence times that consider the full range of key processes that directly affect the physical, chemical and biological composition of the surface microlayer, such as dry and wet deposition fluxes, wind speeds, and neuston composition.

Here, we investigate the dissolved $(<0.22 \mu \mathrm{m})$ and total (unfiltered) trace metal composition $(\mathrm{Cd}, \mathrm{Co}, \mathrm{Cu}, \mathrm{Fe}, \mathrm{Ni}$, $\mathrm{Mo}, \mathrm{V}, \mathrm{Zn}$ and $\mathrm{Pb}$ ) of the SML in the central and western MS. Aerosols were sampled and analyzed for trace metals at the same stations and residence times of particulate aerosol metals in the SML were calculated. The microbial composition and abundance in the SML and subsurface water (SSW), the primary production, and $\mathrm{Chl} a$ concentration in subsurface water $(1-5 \mathrm{~m})$ were analyzed and their relationships with trace metal concentrations and distribution were examined.

\section{Material and methods}

Samples from the SML, the SSW and aerosols were collected during the PEACETIME (ProcEss studies at the AirsEa Interface after dust deposition in the MEditerranean sea) cruise on board the French R/V Pourquoi Pas? in the MS, from 10 May to 11 June 2017 (Guieu et al., 2020). The 12 stations were sampled (Fig. 1). Three of these stations were sampled twice (TYR 1-2, ION 1-2) or five times (FAST 15) on different days, resulting in a total of 17 sets of samples (Tables 1-2).

\subsection{Aerosol sampling and analysis}

A PEGASUS container was installed on board the R/V Pourquoi Pas?. This container is a mobile platform equipped with a set of instruments optimized to collect and analyze gaseous compounds and particles in the atmospheric boundary layer (Formenti et al., 2019) in real time. Atmospheric sampling was performed using isokinetic and wind-oriented aerosol multi-samplers with a total sampling flow rate of ca. $400 \mathrm{~L} \mathrm{~min}^{-1}$ per inlet. This inlet was developed to sample particles with an aerodynamic diameter inferior to $40 \mu \mathrm{m}$ (Rajot et al., 2008). The total flow was subdivided into various transmission lines, which served the majority of the instrumentation. The aerosol size distribution from $10 \mathrm{~nm}$ to $30 \mu \mathrm{m}$ was measured by a combination of standard optical and electrical mobility analyzers (SMPS TSI Scanning Mobility Particle Sizer and GRIMM Inc. optical particle counters, OPC, 1.109). The total mass concentration was obtained by an online Tapering Element Oscillating Microbalance (TEOM, model 1400a, Rupprecht and Patashnick Co.).

One of the sampling lines was equipped with a filtration unit to collect the aerosols on $47 \mathrm{~mm}$ polycarbonate membranes of $0.4 \mu \mathrm{m}$ pore size (Whatman Nuclepore ${ }^{\mathrm{TM}}$ ). The volume flow rate was set at $20 \mathrm{~L} \mathrm{~min}^{-1}$. All filters had been previously cleaned by immersion in ultrapure $\mathrm{HCl}(2 \%)$ over 


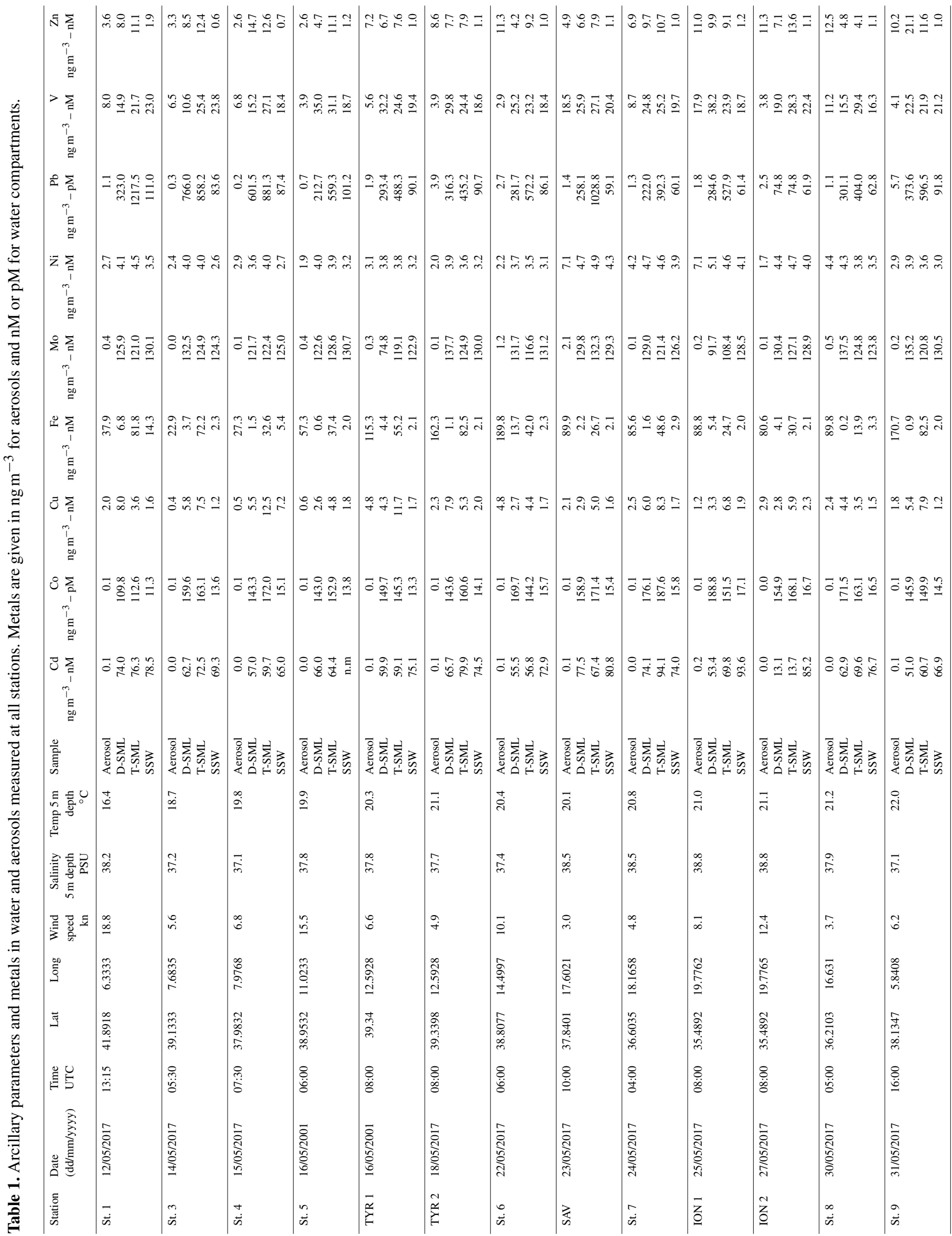




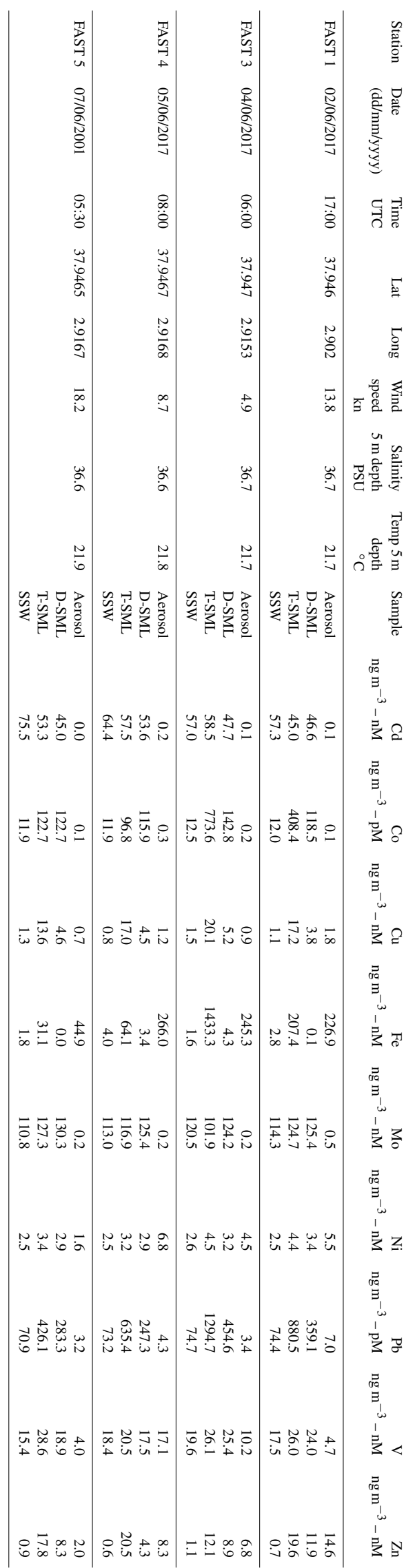

$2 \mathrm{~h}$ and rinsed with ultrapure waters. A sampling strategy was used to avoid contamination by the ship's fumes. First, when the vessel was at the station, the $\mathrm{R} / \mathrm{V}$ was systematically positioned so that the inlets were facing the wind (the PEGASUS container and the ship's stack were on the opposite sides of the deck). While steaming, contamination-free sampling was carried out when the relative wind direction was not in the path of chimney exhaust. In total, 36 series of filters were collected, including 17 filters during the work at the station and 5 blank filters. The sampling locations for each filter are presented in Fig. 1. The aerosol filters were first analyzed by X-ray fluorescence spectrometry (SFX, spectrometer PW2404, Panalytical ${ }^{\mathrm{TM}}$ ) to measure the chemical markers of particle origin sources (such as $\mathrm{Al}$ and $\mathrm{Ca}$ ). The filters were then leached with ultrapure water in order to determine the soluble fraction of metals. Finally, the filters were mineralized using an acid digestion protocol adapted from Heimburger et al. (2013) in order to quantify the insoluble (particulate) fraction of metals. The dissolved and digested samples were analyzed by High Resolution Inductively Coupled Plasma Mass Spectrometry (HR-ICP-MS; Neptune Plus, Thermo Scientific ${ }^{\mathrm{TM}}$ ) for the following trace metals: $\mathrm{Cd}, \mathrm{Co}, \mathrm{Cu}, \mathrm{Fe}, \mathrm{Mo}, \mathrm{Ni}, \mathrm{Pb}, \mathrm{V}$, $\mathrm{Zn}$. The total concentration of metals corresponds to the sum of dissolved and particulate fraction of the metals. Rain was also sampled during the cruise with an online filtration collector $\left(0.2 \mu \mathrm{m}\right.$, polycarbonate, Nuclepore Whatman $\left.{ }^{\mathrm{TM}}\right)(\mathrm{He}-$ imburger et al., 2013), which also analyzed particulate and dissolved metals using HR-ICP-MS.

\subsection{Water sampling and analysis}

\subsubsection{Trace metals}

Surface samples, i.e., SML and subsurface water (SSW: $\sim 1 \mathrm{~m}$ depth), were collected from a pneumatic boat deployed 500-1500 $\mathrm{m}$ from the research vessel in order to avoid contamination of the samples by the vessel. SML samples were collected using a glass plate sampler (Stortini et al., 2012; Tovar-Sánchez et al., 2019) that had been previously cleaned with acid overnight and rinsed thoroughly with ultrapure water (MQ water). Once at the station, the glass plate and the whole sampler were rinsed with seawater several times, and the three first dips (SML samples) were discharged. The $39 \times 25 \mathrm{~cm}$ silicate glass plate had an effective sampling surface area of $1950 \mathrm{~cm}^{2}$ considering both sides. In order to check for procedural contamination, we collected SML blanks at some stations on board the pneumatic boat by rinsing the glass plate with ultrapure water and collecting $0.5 \mathrm{~L}$ using the glass plate system. The sample signal to blank ratio was typically greater than $5: 1$ for all elements. The surface microlayer thickness $(\mu \mathrm{m})$ was calculated using the following formula (Wurl, 2009):

$\mathrm{SML}_{\mathrm{T}}=V_{\mathrm{S}} \times 10^{4} / N\left(A_{\mathrm{p}} \cdot 2\right)$, 
Table 2. Biological parameters measured at all stations: bacteria; high-nucleic-acid-content bacteria: HNA; low-nucleic-acid-content bacteria: LNA; picophytoplankton; transparent exopolymer particles: TEPs; primary production: PP; and chlorophyll $a$ : Chl $a$. n.m: not measured

\begin{tabular}{|c|c|c|c|c|c|c|c|c|}
\hline Station & & $\begin{array}{r}\text { Bacteria } \\
\text { cell } \mathrm{mL}^{-1} \times 10^{5}\end{array}$ & $\begin{array}{r}\text { HNA } \\
\text { cell } \mathrm{mL}^{-1} \times 10^{5}\end{array}$ & $\begin{array}{r}\text { LNA } \\
\text { cell } \mathrm{mL}^{-1} \times 10^{5}\end{array}$ & $\begin{array}{r}\text { Picophyto } \\
\text { cell } \mathrm{mL}^{-1} \times 10^{2}\end{array}$ & $\begin{array}{r}\text { TEP } \\
\text { particles } \mathrm{L}^{-1} \times 10^{6}\end{array}$ & $\begin{array}{r}\text { PP } \\
m g \mathrm{Cm}^{-3} \mathrm{~d}^{-1}\end{array}$ & $\begin{array}{r}\text { Chl } a \\
\mu g \mathrm{~L}^{-1}\end{array}$ \\
\hline \multirow{2}{*}{ St. 1} & T-SML & 3.49 & 1.62 & 1.88 & 84.71 & 7.67 & & \\
\hline & SSW & 3.02 & 1.26 & 1.78 & 70.74 & 4.79 & 5.70 & 0.187 \\
\hline \multirow{2}{*}{ St. 3} & T-SML & 5.06 & 1.80 & 3.30 & 30.76 & 8.24 & & \\
\hline & SSW & 5.68 & 2.10 & 3.62 & 21.72 & 1.50 & 1.65 & 0.095 \\
\hline \multirow{2}{*}{ St. 4} & T-SML & 6.92 & 3.58 & 3.37 & 31.11 & 5.97 & & \\
\hline & SSW & 6.65 & 3.59 & 3.10 & 24.35 & 2.66 & 1.75 & 0.090 \\
\hline \multirow{2}{*}{ St. 5} & T-SML & 4.27 & 2.05 & 2.25 & 16.76 & 4.55 & & \\
\hline & SSW & 4.45 & 2.12 & 2.36 & 13.74 & 2.28 & 1.68 & 0.060 \\
\hline \multirow{2}{*}{ TYR 1} & T-SML & 4.84 & 1.33 & 3.46 & 16.18 & 3.55 & & \\
\hline & SSW & 4.89 & 1.43 & 3.46 & 12.88 & 0.68 & 1.56 & 0.063 \\
\hline \multirow{2}{*}{ TYR 2} & T-SML & 5.53 & 2.00 & 3.57 & 34.60 & 15.10 & & \\
\hline & SSW & 5.00 & 1.87 & 3.16 & 17.26 & 1.84 & 1.77 & 0.071 \\
\hline \multirow{2}{*}{ St. 6} & T-SML & 5.19 & 2.17 & 3.04 & 20.61 & 8.44 & & \\
\hline & SSW & 4.99 & 2.03 & 3.00 & 12.78 & 7.47 & 1.66 & n.m \\
\hline \multirow{2}{*}{ SAV } & T-SML & 3.66 & 1.37 & 2.30 & 13.76 & 19.10 & n.m & n.m \\
\hline & SSW & 3.53 & 1.30 & 2.25 & 12.83 & 3.34 & n.m & n.m \\
\hline \multirow{2}{*}{ St. 7} & T-SML & 3.08 & 1.28 & 1.81 & 20.38 & 8.36 & n.m & n.m \\
\hline & SSW & 3.16 & 1.32 & 1.85 & 15.63 & 2.96 & 0.90 & 0.056 \\
\hline \multirow{2}{*}{ ION 1} & T-SML & 2.11 & 0.81 & 1.30 & 17.08 & 26.55 & & \\
\hline & SSW & 2.19 & 0.88 & 1.32 & 14.29 & 8.20 & 1.84 & n.m \\
\hline \multirow{2}{*}{ ION 2} & T-SML & 2.04 & 0.94 & 1.10 & 19.14 & 13.27 & & \\
\hline & SSW & 2.16 & 0.96 & 1.21 & 9.50 & 7.16 & 1.79 & 0.063 \\
\hline \multirow{2}{*}{ St. 8} & T-SML & 3.70 & 1.62 & 2.10 & 30.59 & 26.13 & & \\
\hline & SSW & 3.24 & 1.48 & 1.77 & 11.64 & 4.65 & 1.64 & 0.070 \\
\hline \multirow{2}{*}{ St. 9} & T-SML & 5.88 & 3.01 & 2.91 & 33.82 & 37.07 & & \\
\hline & SSW & 5.65 & 3.18 & 2.51 & 16.70 & 10.57 & 2.64 & 0.072 \\
\hline \multirow{2}{*}{ FAST 1} & T-SML & 6.20 & 3.55 & 2.68 & 17.11 & 6.93 & & \\
\hline & SSW & 6.09 & 3.76 & 2.38 & 14.53 & 1.27 & 2.68 & 0.070 \\
\hline \multirow{2}{*}{ FAST 3} & T-SML & 9.99 & 5.42 & 4.59 & 44.31 & 37.29 & & \\
\hline & SSW & 6.35 & 3.77 & 2.62 & 18.35 & 2.16 & 2.44 & 0.085 \\
\hline \multirow{2}{*}{ FAST 4} & T-SML & 8.80 & 4.01 & 4.83 & 44.89 & n.m & & \\
\hline & SSW & 6.87 & 3.41 & 3.49 & 43.40 & n.m & 2.85 & 0.081 \\
\hline \multirow{2}{*}{ FAST 5} & T-SML & 6.61 & 3.22 & 3.41 & 25.04 & 3.14 & & \\
\hline & SSW & 6.64 & 3.57 & 3.10 & 23.54 & 2.88 & 2.04 & 0.078 \\
\hline
\end{tabular}

where $V_{\mathrm{S}}$ is the volume sampled $(\mathrm{mL}), N$ the number of dips and $A_{\mathrm{p}}$ the surface area of the glass plate $\left(\mathrm{cm}^{2}\right)$.

The total fraction of SML (i.e., T-SML) was collected directly from the glass plate system without filtration in acidcleaned 0.5 L LDPE bottles, while the dissolved fraction in the SML (i.e., D-SML) was rapidly filtered on board the pneumatic boat through an acid-cleaned polypropylene cartridge filter $\left(0.22 \mu \mathrm{m}\right.$; MSI, Calyx $\left.{ }^{\circledR}\right)$. SSWs $(\sim 1 \mathrm{~m}$ depth $)$ were collected using acid-washed Teflon tubing connected to a peristaltic pump and directly filtered on the same cartridge to collect the dissolved fraction (D-SSW). All samples were acidified on board to $\mathrm{pH}<2$ with ultrapure-grade $\mathrm{HCl}$ in a class-100 HEPA laminar-flow hood. The metals (i.e., Cd, Co, $\mathrm{Cu}, \mathrm{Fe}, \mathrm{Ni}, \mathrm{Mo}, \mathrm{V}, \mathrm{Zn}$ and $\mathrm{Pb}$ ) were stored for at least 1 month prior to analysis. The samples were pre-concentrated using an organic extraction method (Bruland et al., 1979) and quantified by ICP-MS (Perkin Elmer ELAN DRC-e). Prior to preconcentration and to ensure the breakdown of metal-organic complexes and the removal of organic matter (Achterberg et al., 2001; Milne et al., 2010), total fraction samples (i.e., T-SML) were digested using a UV system consisting of a UV $(80 \mathrm{~W})$ mercury lamp that irradiated the samples (contained in quartz bottles) over $30 \mathrm{~min}$. The accuracy of the pre-concentration method and analysis for trace metals was 


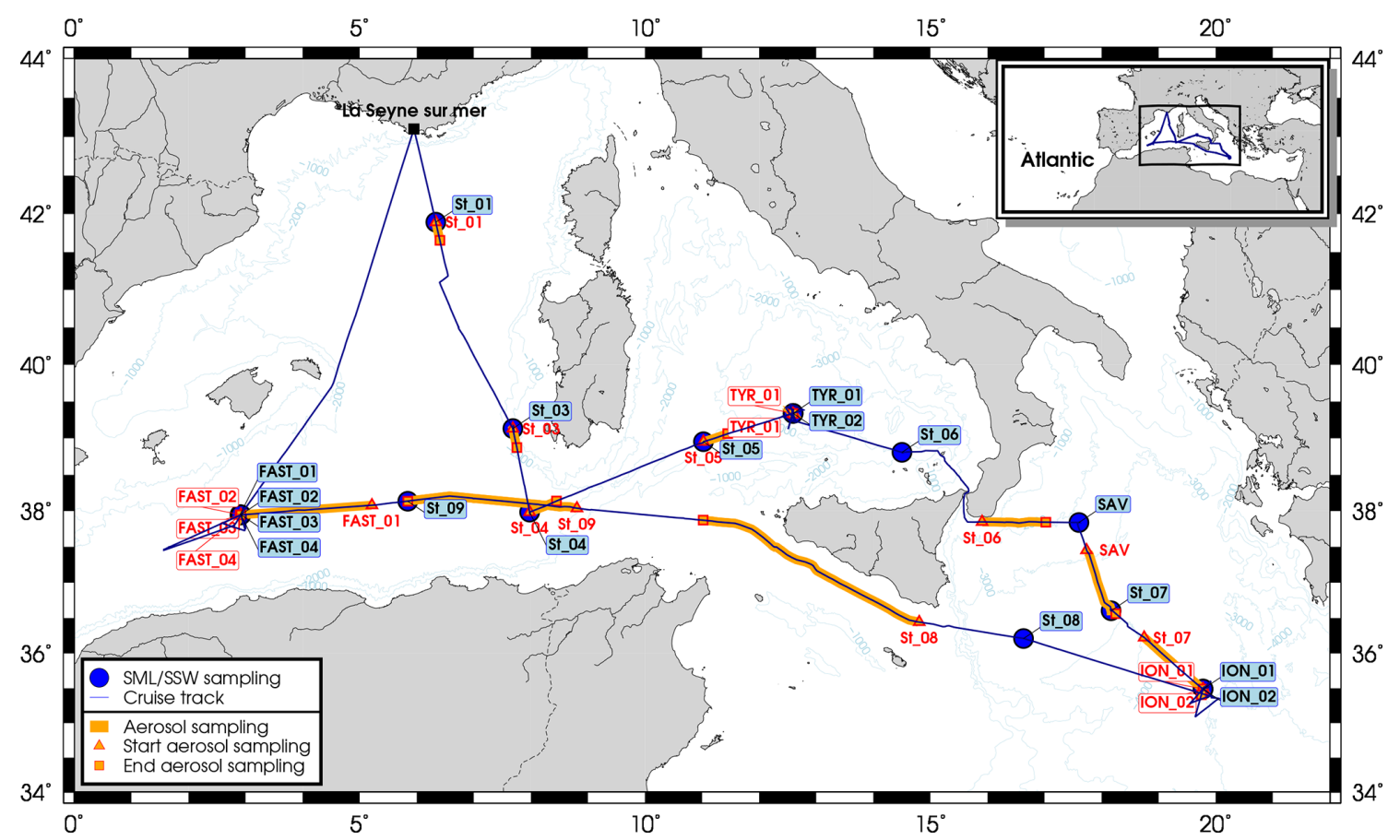

Figure 1. Location of the sampling stations during the PEACETIME cruise (10 May to 11 June 2017).

established using Seawater Reference Material for Trace Elements (CASS 6, NRC-CNRC) and compares well with the following certified values given in brackets (in $\mu \mathrm{g} \mathrm{L}{ }^{-1}$ ): Cd: 0.02 (0.022); Co: 0.07 (0.067); Cu: 0.44 (0.418); Fe: 1.58 (1.56); Mo: 8.1 (9.15); Ni: 0.41 (0.418); Pb:0.01 (0.011); V: 0.45 (0.49); Zn: 1.14 (1.127).

\subsubsection{Ancillary parameters}

The temperature and salinity of the surface seawater were measured with the underway thermosalinograph (TSG) system of the R/V Pourquoi Pas?, which was composed of a Seabird ${ }^{\circledR}$ SBE 21 seaCAT linked to a SBE 38 thermometer situated at the seawater inlet. The seawater inlet was located $3 \mathrm{~m}$ under the sea surface. The wind speed at $10 \mathrm{~m}$ was measured with a Gill Windsonic ultrasonic anemometer from the onboard BATOS station deployed by the French meteorological agency Météo France on the vessel. Temperature, salinity and wind data were binned every $30 \mathrm{~s}$ by the ship's data management system TECHSAS (TECHnical Sensor Acquisition System). The average values of temperature, salinity and wind speed for a time period of $1 \mathrm{~h}$ around the time of SML sampling are shown in Table 1.

\subsection{Biological sampling and analysis}

\subsubsection{Neuston}

The microorganisms inhabiting the SML are collectively referred to as the "neuston" (Engel et al., 2017). The microor- ganisms in the SML were sampled at the same time as the trace metal sample collection, also using a glass plate system $(50 \times 26 \mathrm{~cm}$ silicate glass plate with an effective sampling surface area of $2600 \mathrm{~cm}^{2}$ considering both sides; Cunliffe and Wurl, 2014; Harvey, 1966). The water from the SSW was collected from around a $20 \mathrm{~cm}$ depth in acid-clean borosilicate bottles. The bacterial numbers were determined using flow cytometry from a $4 \mathrm{~mL}$ sample that was fixed with $200 \mathrm{~mL}$ glutaraldehyde (GDA, $1 \%$ final concentration). The samples were stored at $-20^{\circ} \mathrm{C}$ for 2.5 months at most until analysis and were then stained with SYBR Green I (Molecular Probes Inc.) (Marie et al., 1997). The samples were analyzed using a flow cytometer equipped with a $488 \mathrm{~nm}$ laser (Becton \& Dickinson FACSCalibur). A plot of side scatter (SSC) vs. green fluorescence (FL1) was used to detect the unique signature of the bacterial cells. The internal standard consisted of yellow-green latex beads (Polysciences, $0.5 \mu \mathrm{m}$ ). The abundance and area of transparent exopolymer particles (TEPs) were measured microscopically following a previously described method (Engel, 2009).

\subsubsection{Phytoplankton and primary production}

Chl $a$ concentration and primary production were measured in the SSW at a depth of $5 \mathrm{~m}$. The primary production was measured with the ${ }^{14} \mathrm{C}$-uptake technique, following the methods detailed in (Marañón et al., 2000). The seawater samples, collected in Niskin bottles at dawn, were dispensed into four (three light and one dark) polystyrene bottles that were $70 \mathrm{~mL}$ in volume, which were amended with $15 \mu \mathrm{Ci}$ of 
$\mathrm{NaH}^{14} \mathrm{CO}_{3}$ and incubated for $24 \mathrm{~h}$ inside a deck incubator refrigerated with surface seawater from the continuous water supply. The incubator was covered with a neutral density filter that provided an irradiance level of $70 \%$ of incident PAR. After incubation, the samples were filtered, using low vacuum pressure, through $0.2 \mu \mathrm{m}$ polycarbonate filters. The filters were then exposed to $\mathrm{HCl}$ fumes overnight to remove non-fixed, inorganic ${ }^{14} \mathrm{C}$. After adding $5 \mathrm{~mL}$ of liquid scintillation cocktail to the filters, the radioactivity of each sample was determined on board with a liquid scintillation counter. The dark-bottle DPM value was subtracted from the light bottle DPM value to compute the rates of carbon fixation. A value of $26663 \mu \mathrm{gC} \mathrm{L}^{-1}$ was used for the concentration of dissolved inorganic carbon (DIC), which corresponds to the mean DIC concentration at $5 \mathrm{~m}$ measured during the cruise. Chl $a$ concentrations were measured by HPLC (HPLC Agilent Technologies 1200) following the method described by Ras et al. (2008).

\subsection{Statistical analyses}

The Spearman rank correlation coefficient $\left(r_{\mathrm{s}}\right)$ was used to determine significant relationships $(p<0.05)$ between the variables measured in the different compartments (air, SML and SSW). Least-square linear regressions and determination coefficients $\left(R^{2}\right)$ were calculated to ascertain the relationship between selected variables. Statistical analyses were performed with the aid of the statistical software package SPSS 25.

\section{Results and discussion}

\subsection{Aerosol depositions}

Metal aerosol compositions are shown in Table 1. The range $\left(\mathrm{ng} \mathrm{m}^{-3}\right)$ of concentrations in our study $(\mathrm{Cd}: 0-0.2$; Co: 0.05-0.3; Cu: 0.4-4.8; Fe: 23-266; Ni: 1.6-7.1; Mo: 0.02.1; V: 3-18; Zn: 2.0-14.6; and Pb: 0.2-7.0) was of the same order of magnitude as previous measurements collected in the same region and season (Becagli et al., 2012; Calzolai et al., 2015, p. 10; Guerzoni et al., 1997; Tovar-Sánchez et al., 2014; Heimbürger et al., 2010) and were therefore consistent with western Mediterranean background concentrations. However, concentrations of trace metals (i.e., $\mathrm{Pb}, \mathrm{Cd}$ and $\mathrm{Zn}$ ) have decreased remarkably over the last 2 decades, while crustal metals have not shown any evolution (Heimbürger et al., 2010). No clear gradient (north-south or eastwest) in the concentrations of atmospheric metals was observed during the cruise. The composition of metal aerosols was mainly influenced by air masses from northern Europe and the Atlantic Ocean (Fig. S1 in the Supplement), except between 1 and 5 June (i.e., for the stations St. 9 and FAST 14) when African air masses were loaded with dust (Figs. S1 and S2). During this period, the aerosol mass concentrations were the highest observed during the cruise, with a maxi- mum of around $25 \mu \mathrm{g} \mathrm{m}^{-3}$ (Fig. S3). Nevertheless, these concentrations were typical of a moderate dust event (Pey et al., 2013). The aerosol Fe concentrations during this period, which averaged $245 \mathrm{ng} \mathrm{m}^{-3}$, were the highest measured during the cruise. The same observation was made for Co. A positive correlation between $\mathrm{Ni}$ and $\mathrm{V}$ in the aerosols collected throughout the cruise suggest a common source associated with heavy oil combustion, i.e., marine ship traffic (Becagli et al., 2012). Some rain events occurred during the cruise, one measured when the vessel was at station, 5 June from 02:36 to 03:04 UTC (between FAST 3 and FAST 4 samples). However, the whole zone around the FAST station was rainy from 3 June (Fig. S4). As the rain composition collected was typical of wet dust deposition with high particulate concentrations of $\mathrm{Al}, \mathrm{Fe}$ and $\mathrm{Ca}$ (Fu et al., 2020), we suppose that the raining out of the dust in the atmospheric column around this station occurred between 3 and 5 June, and hence dusty rain events impacted the concentration of surface waters during the FAST stations. The total trace metal concentrations in the dusty rain collected, ranged from $180 \mathrm{pM}$ for $\mathrm{Cd}$ to $343 \mathrm{nM}$ for $\mathrm{Fe}(\mathrm{Cd}: 180 \mathrm{pM}$; Co: $1380 \mathrm{pM}$; $\mathrm{Cu}$ : $18.1 \mathrm{nM}$; Fe: 343 nM; Ni: 9.9 nM; Mo: 875 pM; V: 26.9 nM; $\mathrm{Zn:} 345 \mathrm{nM}$; and $\mathrm{Pb}: 788 \mathrm{pM}$ ).

\subsection{Biochemical composition and distribution of the surface water}

Trace metal concentrations in the surface waters of the MS varied depending on the layer sampled (i.e., SML or SSW) and along a longitudinal gradient (Table 1).

\subsection{Trace metals in the SML}

With the exception of $\mathrm{Pb}$, trace metal concentrations of $\mathrm{T}$ SML (Table 1) were lower (but of the same order of magnitude) than those measured in a previous study carried out in the MS (Tovar-Sánchez et al., 2014). The lower content of metals in the SML is probably related to the low dust aerosol deposition during our sampling period and the lack of desert dust aerosols, except for at the FAST station. TSML average concentration $( \pm \mathrm{SD})$ of $\mathrm{Pb}(663 \pm 320 \mathrm{pM})$ was an order of magnitude lower than in previous studies that investigated pulses of both mineral African dust and anthropogenic aerosols coming from Europe $(5596 \pm 1589 \mathrm{pM})$ (Tovar-Sánchez et al., 2014). The highest concentrations of some metals were measured at the FAST 3 station (Co: $773.6 \mathrm{pM}$; Cu: $20.1 \mathrm{nM}$; Fe: $1433.3 \mathrm{nM}$; and Pb: $1294.7 \mathrm{pM}$ ), which was probably affected by the dusty rain events on this area.

Dissolved concentrations of $\mathrm{Co}, \mathrm{Zn}, \mathrm{Pb}, \mathrm{Cu}$ and $\mathrm{Ni}$ showed a decreasing trend from the SML to the SSW, with average concentrations that were $( \pm \mathrm{SD}) 10.4 \pm 0.7,9.3 \pm 5.5$, $4.2 \pm 1.8,3.1 \pm 1.5$, and $1.2 \pm 0.1$ times higher in the SML than in the SSW, respectively. The SML to SSW concentration ratio for $\mathrm{V}(1.2 \pm 0.42)$ and $\mathrm{Fe}(1.3 \pm 1.5)$ indicated 
only slight enrichment in the SML, while the ratio for Mo $(1.0 \pm 0.1)$ indicated no difference between layers (Table 1$)$. Only Cd concentrations were consistently lower in the SML compared to the underlying water $(0.8 \pm 0.2$ times lower). Such a low ratio of dissolved metals (as it is the case for $\mathrm{Cd}$ ) in the SML compared to the underlying water has been previously observed in areas without significant aerosol inputs (Ebling and Landing, 2015, 2017). Although not fully understood, some mechanisms, such as the dominance of removal processes over diffusion or the higher influence of metal sources from underlaying water, have been suggested previously to explain this difference of metal concentrations between compartments (Ebling and Landing, 2017; Hunter, 1980). Given the high exposure to solar radiation and the enrichment in organic matter, photoreaction is likely to play an important role, driving redox processes that alter metal speciation and complexation between inorganic and organic species and affecting the distribution of species in the SML and their transfer to the SSW. Photoredox processes in the SML are not fully understood; however, the strong dependence of redox seawater chemistry and complexation of elements such as $\mathrm{Cu}$ and $\mathrm{Fe}$ on solar radiation have been studied (Croot and Heller, 2012; Moffett and Zika, 1988). Thus, for example $\mathrm{Fe}$ (III) and $\mathrm{Cu}$ (II) could be photochemically reduced in surface seawaters to highly soluble $\mathrm{Fe}(\mathrm{II})$ and $\mathrm{Cu}$ (I) (Sunda, 2012). Although these reduced states are unstable in oxygenated waters and are re-oxidized and re-chelated by organic ligands on timescales of minutes (Sunda, 2012), the continuous and intense UV radiation in the SML could be intensifying these reactions, and enhancing the transfer between SML and SSW and its effect on phytoplankton.

The spatial distribution of $\mathrm{Co}$ and $\mathrm{Ni}$ concentrations in the D-SML was well correlated with that observed in the D-SSW (Spearman's correlation coefficient, $r_{\mathrm{s}}: 0.87$ for Co and 0.91 for Ni; $p<0.01$, Table 3), indicating an efficient diffusive transfer between these two compartments for these elements. The concentration of these elements was also positively correlated with the surface salinity distribution $\left(r_{\mathrm{s}}: 0.62\right.$ for Co and 0.93 for $\mathrm{Ni} ; p<0.01$, Table 3 ), and presented an eastward trend of increasing concentration, which is consistent with the characteristic distribution of metals on the surface of the MS (see Sect. 3.2.4. below). The variations in concentrations for the rest of the elements (i.e., $\mathrm{Cd}, \mathrm{Cu}, \mathrm{Fe}, \mathrm{Pb}, \mathrm{V}$ and $\mathrm{Zn}$ ) in the D-SML were correlated with neither the concentration in the underlying water nor the salinity. Multiple physical, chemical and biological processes taking place in the SML could affect the mobility and diffusion of these elements between compartments. However, the concentrations of $\mathrm{Cu}, \mathrm{Fe}$ and $\mathrm{Zn}$ in the T-SML showed an opposite longitudinal trend to that of salinity $\left(r_{\mathrm{s}}:-0.59\right.$ for $\mathrm{Cu},-0.69$ for $\mathrm{Fe}$ and -0.61 for $\mathrm{Zn} ; p<0.01$, Table 3). No correlations between T-SLM and D-SLM trace metal concentrations were found except for $\mathrm{Cd}(0.789 p<0.01)$ and $\mathrm{Ni}(0.681$ $p<0.01)$. Since aerosol metal concentrations did not show any longitudinal trend and no other natural or anthropogenic sources were identified in the region, the longitudinal gradient in the concentration of these reactive trace elements in the T-SML must have been influenced by factors other than source inputs, water exchange or dilution with Atlantic waters. The complex matrix of the SML and the particular organic and inorganic speciation of each metal studied in the SML will affect their distribution. Thus, for example, $\mathrm{Cd}$ and $\mathrm{Zn}$ characterized by an oxidation state number of II can vary from very weak to very strong complexation. Lead in oxygenated seawater is partitioned between chloride and carbonate complexes, while $\mathrm{Fe}$ and $\mathrm{Cu}$ speciation are strongly influenced by $\mathrm{pH}$ (Byrne, 2002).

\subsubsection{Residence time of trace metals in the SML}

Estimates of the residence times of metals from aerosol deposition in the SML are critical to understanding the biogeochemical processes that affect the fate and distribution of trace metals in the oceans' surface more. The equation proposed by Ebling and Landing (2017) was used to estimate the residence time $(t)$ of particulate metals in the SML:

$t=[\mathrm{TE}]_{\mathrm{SML}} \times d / J_{\text {aerosol }}$,

where $[\mathrm{TE}]_{\mathrm{SML}}$ is the concentration of the trace element (TE) in the T-SML, $d$ is the thickness of the SML and $J_{\text {aerosol }}$ is the aerosol trace metal flux measured. $J_{\text {aerosol }}$ was estimated by multiplying the metal aerosol concentrations with the deposition velocity, which is dependent on aerosol size. During the cruise, $\mathrm{Al}$ and $\mathrm{Fe}$ atmospheric concentrations were correlated at all the stations and the ratio $\mathrm{Fe} / \mathrm{Al}$ is typical of a crustal source (Fu et al., 2020). The atmospheric iron deposition fluxes are associated with mineral dust particles even during the period when the Saharan dust inputs are very low (Desboeufs et al., 2018; Guieu et al., 2010). Conversely, no correlation with $\mathrm{Al}$ is observed for the other metals, except during FAST 1-3. Thus, we used a mineral dust deposition velocity for $\mathrm{Fe}$ of $1 \mathrm{~cm} \mathrm{~s}^{-1}$ and an average velocity of fine anthropogenic particles for the other metals, i.e., $0.1 \mathrm{~cm} \mathrm{~s}^{-1}$ (Baker et al., 2010; Duce et al., 1991). For the calculations of the residence times throughout our different stations we used simultaneous empirical measurements of total metal concentrations in the SML (assuming that the metal in the total fraction is highly influenced by material from aerosol dust) and metal aerosol fluxes. Since Mo and $\mathrm{Cd}$ are not enriched in the SML they were not considered in this calculation. Although highly variable among stations, the average residence times $( \pm \mathrm{SD})$ of $\mathrm{Cu}(5.8 \pm 6.2 \mathrm{~h}), \mathrm{V}(2.2 \pm 1.0 \mathrm{~h}), \mathrm{Pb}(1.8 \pm 3.4 \mathrm{~h})$, $\mathrm{Zn}(1.5 \pm 1.2 \mathrm{~h}), \mathrm{Co}(1.2 \pm 0.7 \mathrm{~h}), \mathrm{Ni}(48 \pm 18 \mathrm{~min})$ and $\mathrm{Fe}$ $(3.6 \pm 6 \mathrm{~min})$ were consistent with previous estimates in regions under low aerosol inputs (Ebling and Landing, 2017) (Table 4). The residence time calculation of Fe using the same deposition rate as rest of the metals (i.e., $0.1 \mathrm{~cm} \mathrm{~s}^{-1}$ ) results in a residence time that is 10 times longer (i.e., average $0.6 \mathrm{~h}$ instead $0.06 \mathrm{~h}$ ), even so, the residence time of $\mathrm{Fe}$ remains the shortest of all studied metals. The residence time 


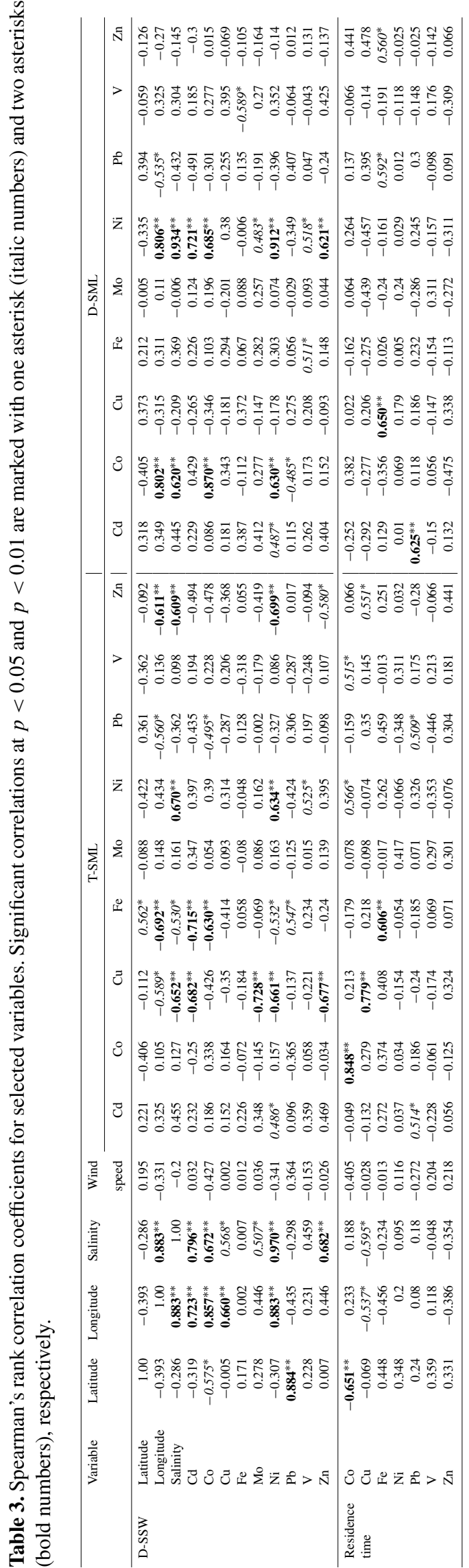

of $\mathrm{Cu}$ (St. 3-4 and FAST 3-4), Fe (St. 3 and FAST 3) and $\mathrm{Pb}$ (St. 4) were an order of magnitude higher than other stations. Our results indicate that FAST 1-4 stations were affected by the dusty rain events, which increased the concentration of some metals and consequently the residence time in the $\mathrm{T}$ SML (Table 4). However, the reasons for the increase at stations St. 3 and St. 4 are not evident. On average, while the highest residence times obtained for $\mathrm{Cu}$ and $\mathrm{Pb}$ are in agreement with their strong affinity to particles and therefore with a high probability of retention in the SML, other reactive elements such as Fe presented the shortest residence times. Since such a quick transfer of these metal particles to the underlying water (on the order of minutes) is unlikely (mainly due to the high content of organic matter in the SML) and the dissolution is not immediately reflected in an increase in the concentration in the dissolved fraction (i.e., D-SML), other variables (linked to physical processes, photochemistry or biological activity) probably affected the residence time of metals in the SML. Wind speed seems to not have affected the residence time of any metal in the SML (Table 3), which is probably due to the low speed registered during our campaign $(9 \pm 4.99 \mathrm{kn})($ Table 1$)$.

\subsubsection{Neuston composition}

The abundance of different microbial groups (bacteria; high-nucleic-acid-content bacteria: HNA; low-nucleic-acidcontent bacteria: LNA; picophytoplankton) in the SML is shown in Table 2. Bacterial abundance in the SML ranged from $2 \times 10^{5}$ to $1 \times 10^{6}$ cell $\mathrm{mL}^{-1}$ (average \pm SD: $5.1 \times 10^{5} \pm$ $2.2 \times 10^{5} \mathrm{cell} \mathrm{mL}^{-1}$ ), which is of the same order of magnitude as the abundance measured in the SML of the coastal Mediterranean Sea (Joux et al., 2006; Obernosterer et al., 2005) and other regions (e.g., along the Peruvian Coast, with an average of $8.9 \times 10^{5} \pm 4.3 \times 10^{5}$ cell $\mathrm{mL}^{-1}$ ) (Agogue et al., 2005; Engel and Galgani, 2016; Joux et al., 2006; Zäncker et al., 2018). The bacterial community was dominated by low-nucleic-acid-content bacteria (LNA) with an average abundance $( \pm \mathrm{SD})$ of $2.8 \times 10^{5} \pm 1.0 \times 10^{5}$ cell $\mathrm{mL}^{-1}$. Bacterial abundances did not differ significantly between SML and SSW (Table 2) in line with previous studies in coastal Mediterranean Sea that reported that the SML was only weakly enriched in heterotrophic bacteria (on average 1.1-fold in Joux et al., 2006, and mean 1.3 in Obernosterer et al., 2005) and comparable to the ratio in other environments, such as the Pacific (Obernosterer et al., 2008). Phytoplankton was only slightly (but significantly; $t$ test, $p=0.002, n=12$ ) enriched in the SML with an average enrichment of $1.5 \mathrm{com}$ pared to the SSW; such enrichments were also observed at coastal sites of the Mediterranean Sea (Joux et al., 2006).

Microbial abundance decreases from west to east, reflecting the increasing oligotrophy (mostly due to $\mathrm{P}$ limitation) of the surface of Mediterranean waters (Pulido-Villena et al., 2012). Microbial abundance in the SML and reactive elements (i.e., $\mathrm{Cu}, \mathrm{Fe}$, and $\mathrm{Zn}$ ) in the T-SML showed the same 
Table 4. Number of dips conducted to collect $500 \mathrm{~mL}$ of SML, thickness $(\mu \mathrm{m})$ of the SML and calculated residence times (h) of particulate metals in the SML derived for aerosol depositions.

\begin{tabular}{lrrrrrrrrr}
\hline Station & Dips & Thickness & $\mathrm{Co}$ & $\mathrm{Cu}$ & $\mathrm{Fe}$ & $\mathrm{Ni}$ & $\mathrm{Pb}$ & $\mathrm{V}$ & $\mathrm{Zn}$ \\
\hline St. 1 & 100 & 26 & 0.5 & 0.8 & 0.09 & 0.7 & 1.6 & 1.0 & 1.5 \\
St. 3 & 60 & 43 & 1.2 & 16.0 & 0.21 & 1.2 & 7.7 & 2.4 & 3.0 \\
St. 4 & 60 & 43 & 1.5 & 19.6 & 0.08 & 1.0 & 13.1 & 2.4 & 3.8 \\
St. 5 & 100 & 26 & 0.7 & 3.4 & 0.03 & 0.9 & 1.2 & 2.9 & 2.0 \\
TYR 1 & 60 & 43 & 0.7 & 1.9 & 0.03 & 0.8 & 0.7 & 2.7 & 0.8 \\
TYR 2 & 60 & 43 & 1.0 & 1.8 & 0.03 & 1.3 & 0.3 & 3.8 & 0.7 \\
St. 6 & 80 & 32 & 0.7 & 0.5 & 0.01 & 0.8 & 0.4 & 3.6 & 0.5 \\
SAV & 60 & 43 & 1.1 & 1.8 & 0.02 & 0.5 & 1.8 & 0.9 & 1.3 \\
St. 7 & 60 & 43 & 1.7 & 2.5 & 0.04 & 0.8 & 0.7 & 1.8 & 1.2 \\
ION 1 & 60 & 43 & 1.2 & 4.2 & 0.02 & 0.4 & 0.7 & 0.8 & 0.6 \\
ION 2 & 80 & 32 & 1.8 & 1.1 & 0.02 & 1.5 & 0.1 & 3.4 & 0.7 \\
St. 8 & 60 & 43 & 1.6 & 1.1 & 0.01 & 0.6 & 0.9 & 1.6 & 0.3 \\
St. 9 & 80 & 32 & 0.9 & 2.5 & 0.02 & 0.7 & 0.2 & 2.4 & 0.7 \\
FAST 1 & 100 & 26 & 1.3 & 4.4 & 0.04 & 0.3 & 0.2 & 2.0 & 0.6 \\
FAST 3 & 60 & 43 & 3.5 & 16.2 & 0.39 & 0.7 & 1.0 & 1.5 & 1.4 \\
FAST 4 & 60 & 43 & 0.2 & 10.7 & 0.02 & 0.3 & 0.4 & 0.7 & 1.9 \\
FAST 5 & 100 & 26 & 1.0 & 9.3 & 0.03 & 0.9 & 0.2 & 2.6 & 4.2 \\
\hline Average & 72.9 & 36.8 & 1.2 & 5.8 & 0.06 & 0.8 & 1.8 & 2.2 & 1.5 \\
SD & 17.2 & 7.6 & 0.7 & 6.2 & 0.10 & 0.3 & 3.4 & 1.0 & 1.2 \\
\hline
\end{tabular}

longitudinal gradients in this study, with a decreasing eastward concentration along the southern coast of the MS. In fact, bacterial abundances were significantly and positively correlated with these bioactive T-SML metals (i.e., $r_{\mathrm{s}}$ : $\mathrm{Cu}$ : $0.65 p<0.01$; Fe: $0.53 p<0.05$; and Zn: $0.49 p<0.05$ ), suggesting that bacterioneuston could affect the concentration and fate of $\mathrm{Cu}, \mathrm{Fe}$ and $\mathrm{Zn}$ in the SML. Bacteria could efficiently assimilate the fraction of $\mathrm{Cu}, \mathrm{Fe}$ and $\mathrm{Zn}$ available, favoring a decrease in the D-SML fraction (Tables 1-2). No general relationship between the concentrations of metals and TEPs (high-molecular-weight polymers released by phytoplankton and bacteria, with a high metal-binding capacity; Passow, 2002) were found in the SML (Table 5). Metal assimilation by microbial communities could explain the higher residence time of $\mathrm{Cu}$ and $\mathrm{Zn}$ (on the order of hours) in the SML, although information about the metal content in seston would be necessary to corroborate this hypothesis. However, in the case of Fe with an estimated residence time of a few minutes, other processes in addition to wind speed and neuston uptake should contribute to facilitating the transfer from the SML to the underlying water. For example, photochemical reactions driven by exposure to intense solar radiation in the SML could play an important role in the dissolution processes of this metal (Boyd et al., 2010). On the other hand, Ni was strongly and negatively correlated with bacterial abundance in the D-SML $\left(r_{\mathrm{s}}=-0.93\right.$, $\left.p<0.01 ; R^{2}=0.74, p<0.01\right)$ suggesting, in contrast to $\mathrm{Cu}, \mathrm{Fe}$ and $\mathrm{Zn}$, a possible inhibiting role on the microbial growth (Table 5 and Fig. 2) (see the next section for more discussion).

\subsubsection{Subsurface water}

The D-SSW concentrations of $\mathrm{Cd}, \mathrm{Co}, \mathrm{Cu}, \mathrm{Ni}, \mathrm{Mo}$ and $\mathrm{Zn}$ showed a longitudinal gradient of concentrations increasing from west to east, with significant positive correlations with longitude for $\mathrm{Cd}\left(r^{2}: 0.60 ; p<0.05\right)$, Co $\left(r^{2}: 0.77\right.$; $p<0.01)$ and $\mathrm{Ni}\left(r^{2}: 0.80 ; p<0.01\right)$ (Fig. 3). This trend is consistent with previous studies, where the increasing eastward trend in concentration along the southern coast of the MS has been suggested to result from several factors, such as more intense Saharan deposition on the eastern MS (Guieu et al., 2002); more rapid exchange of water masses and margin inputs in the western MS (Yoon et al., 1999); or, as suggested for $\mathrm{Co}$, the eastward regeneration of biogenic particulates, which yields a decrease towards the west of the dissolved Co in surface water (Dulaquais et al., 2017). Since surface salinity showed the same eastward increase and was closely correlated with those metals $\left(r_{\mathrm{s}}\right.$ ranged from $0.51 p<0.05$ for Mo to $0.97 p<0.01$ for Ni; Table 3), the exchange with the surface Atlantic Ocean waters seems to be the main cause of this gradient of concentrations in our study. Other metals (i.e., $\mathrm{Fe}, \mathrm{Pb}$ and $\mathrm{V}$ ) did not show any clear geographical trend, and therefore the variations in their surface concentrations could be influenced by factors other than dilution or exchange, such as vertical diffusive fluxes or specific metal sources, as in the case of $\mathrm{Fe}$ and $\mathrm{Pb}$, which have been suggested to be more affected by atmospheric inputs (Nicolas et al., 1994; Yoon et al., 1999). In fact, $\mathrm{Pb}$ was the only element that showed significant positive correlation with latitude $\left(r_{\mathrm{s}}\right.$ : 


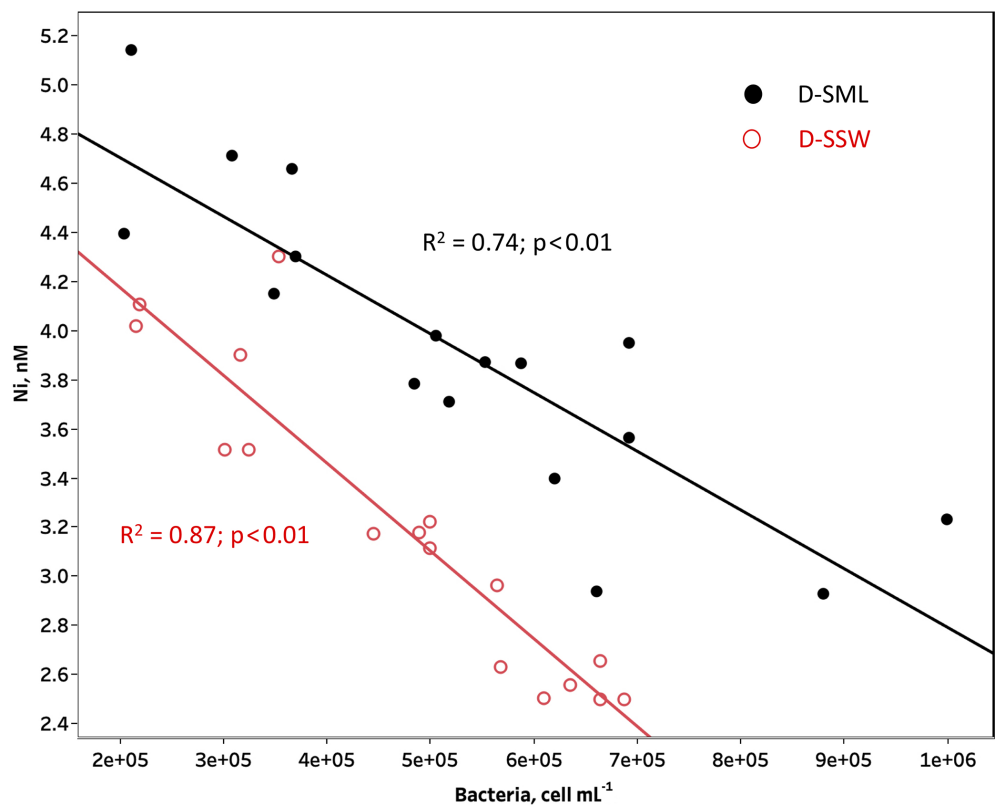

Figure 2. Concentration of dissolved Ni plotted against bacterial abundance in both the surface microlayer (SML, black dots) and subsurface water (SSW, red open dots). The lines represent least-square linear regressions.

Table 5. Spearman's rank correlation coefficients for selected parameters: bacteria; HNA: high-nucleic-acid-content bacteria; LNA: lownucleic-acid-content bacteria; picophyto: picophytoplankton; transparent exopolymer particles: TEPs; primary production: PP; and chlorophyll $a$ : Chl $a$. Significant correlations at $p<0.05$ and $p<0.01$ are marked with one asterisk (italic numbers) and two asterisks (bold numbers), respectively.

\begin{tabular}{|c|c|c|c|c|c|c|c|c|c|c|c|c|c|}
\hline \multirow{2}{*}{\multicolumn{2}{|c|}{ Variable }} & \multicolumn{5}{|c|}{ SML } & \multicolumn{7}{|c|}{ SSW } \\
\hline & & Bacteria & HNA & LNA & Picophyto & TEP & Bacteria & HNA & LNA & Picophyto & TEP & PP & Chl $a$ \\
\hline \multirow{4}{*}{\multicolumn{2}{|c|}{$\begin{array}{l}\text { Longitude } \\
\text { Temperature } \\
\text { Salinity } \\
\text { Wind speed }\end{array}$}} & $-0.815^{* *}$ & $-0.842^{* *}$ & $-0.619^{* *}$ & $-0.485^{*}$ & 0.249 & $-\mathbf{0 . 7 8 5} 5^{* *}$ & $-\mathbf{0 . 8 3 1} 1^{* *}$ & $-0.516^{*}$ & $-0.667^{* *}$ & 0.416 & $-0.630^{* *}$ & $-0.585^{*}$ \\
\hline & & 0.427 & 0.377 & 0.265 & 0.191 & 0.377 & 0.341 & 0.394 & 0.011 & -0.012 & 0.144 & 0.42 & -0.132 \\
\hline & & $-0.958^{* *}$ & $-0.927^{* *}$ & $-0.797^{* *}$ & -0.453 & 0.238 & $-0.957^{* *}$ & $-0.927^{* *}$ & $-\mathbf{0 . 7 1 3}^{* *}$ & $-0.565^{*}$ & 0.422 & -0.412 & -0.475 \\
\hline & & 0.049 & 0.183 & -0.109 & 0.031 & $-0.578^{*}$ & 0.054 & 0.114 & -0.054 & 0.232 & 0.078 & $0.521^{*}$ & 0.187 \\
\hline \multirow[t]{9}{*}{ T-SML } & $\mathrm{Cd}$ & -0.407 & -0.43 & -0.238 & 0.161 & 0.203 & -0.377 & -0.439 & -0.11 & 0.186 & 0.044 & -0.315 & 0.024 \\
\hline & Co & -0.012 & 0.009 & -0.174 & -0.229 & 0.285 & -0.029 & 0.176 & -0.245 & -0.243 & -0.326 & -0.265 & -0.222 \\
\hline & $\mathrm{Cu}$ & $0.654^{* *}$ & $0.538^{*}$ & $0.542^{*}$ & 0.12 & -0.182 & $0.684^{* *}$ & $0.650^{* *}$ & 0.453 & 0.441 & -0.468 & 0.3 & 0.191 \\
\hline & $\mathrm{Fe}$ & $0.527^{*}$ & $0.515^{*}$ & $0.488^{*}$ & $0.493^{*}$ & 0.024 & 0.449 & $0.502^{*}$ & 0.449 & $0.493^{*}$ & -0.421 & 0.424 & 0.371 \\
\hline & $\mathrm{Ni}$ & $-0.610^{* *}$ & $-0.530^{*}$ & $-0.669^{* *}$ & -0.347 & 0.268 & $-0.600^{*}$ & -0.48 & $-0.667^{* *}$ & -0.248 & 0.15 & -0.044 & -0.116 \\
\hline & Mo & -0.238 & -0.179 & -0.228 & -0.353 & -0.344 & -0.115 & -0.088 & -0.103 & -0.186 & -0.191 & -0.206 & -0.288 \\
\hline & $\mathrm{Pb}$ & 0.436 & $0.514^{*}$ & 0.319 & 0.307 & 0.106 & 0.407 & 0.397 & 0.245 & 0.478 & -0.138 & $0.524^{*}$ & $0.754^{* *}$ \\
\hline & $\mathrm{V}$ & -0.096 & -0.039 & -0.201 & -0.45 & -0.229 & -0.066 & 0.135 & -0.257 & -0.387 & -0.265 & -0.371 & -0.349 \\
\hline & $\mathrm{Zn}$ & $0.493^{*}$ & $0.579^{*}$ & 0.225 & 0.34 & -0.306 & $0.561^{*}$ & $0.569^{*}$ & 0.245 & $0.527^{*}$ & -0.126 & $0.594^{*}$ & 0.371 \\
\hline \multirow[t]{9}{*}{ D-SML } & $\mathrm{Cd}$ & -0.385 & -0.354 & -0.174 & -0.085 & -0.038 & -0.338 & -0.397 & -0.047 & -0.005 & -0.082 & -0.465 & -0.108 \\
\hline & Co & $-0.583^{*}$ & $-0.667^{* *}$ & -0.458 & -0.444 & 0.412 & $-0.539^{*}$ & $-0.559^{*}$ & -0.309 & $-0.627^{* *}$ & 0.376 & $-0.732 * *$ & -0.495 \\
\hline & $\mathrm{Cu}$ & 0.221 & 0.151 & 0.26 & $0.712^{* *}$ & 0.021 & 0.233 & 0.123 & 0.299 & $\mathbf{0 . 7 3 8}^{* *}$ & -0.182 & 0.112 & $0.547^{*}$ \\
\hline & $\mathrm{Fe}$ & -0.301 & -0.327 & -0.078 & 0.08 & 0.221 & -0.346 & -0.471 & -0.044 & -0.047 & 0.259 & -0.029 & 0.279 \\
\hline & $\mathrm{Ni}$ & $-0.926^{* *}$ & $-\mathbf{0 . 8 8 8}^{* *}$ & $-0.826^{* *}$ & -0.383 & 0.356 & $-\mathbf{0 . 8 8 9}^{* *}$ & $-\mathbf{0 . 8 5 3}^{* *}$ & $-0.690^{* *}$ & -0.462 & 0.453 & -0.393 & -0.4 \\
\hline & Mo & -0.056 & -0.042 & -0.034 & 0.311 & 0.359 & -0.061 & -0.088 & 0.005 & -0.137 & 0.253 & -0.079 & -0.002 \\
\hline & $\mathrm{Pb}$ & 0.48 & 0.41 & 0.375 & 0.472 & 0.121 & 0.451 & 0.449 & 0.385 & 0.475 & -0.315 & 0.182 & $0.732^{* *}$ \\
\hline & V & -0.191 & -0.265 & -0.037 & $-0.574^{*}$ & 0.174 & -0.277 & -0.208 & -0.152 & -0.468 & -0.076 & -0.182 & $-0.670^{* *}$ \\
\hline & $\mathrm{Zn}$ & 0.154 & 0.109 & -0.093 & 0.151 & 0.129 & 0.164 & 0.238 & -0.061 & 0.377 & -0.003 & 0.232 & 0.275 \\
\hline \multirow[t]{9}{*}{ D-SSW } & $\mathrm{Cd}$ & $-0.826^{* *}$ & $-0.837^{* *}$ & $-0.638^{* *}$ & -0.421 & 0.068 & $-0.800^{* *}$ & $-0.882^{* *}$ & $-0.579^{*}$ & -0.429 & 0.443 & -0.211 & -0.28 \\
\hline & Co & $-0.586^{*}$ & $-0.591^{*}$ & $-0.591^{*}$ & -0.418 & 0.491 & $-0.586^{*}$ & $-0.532^{*}$ & $-0.537^{*}$ & $-0.694^{* *}$ & $0.568^{*}$ & $-0.541^{*}$ & $-0.538^{*}$ \\
\hline & $\mathrm{Cu}$ & -0.412 & -0.424 & -0.284 & -0.28 & -0.059 & -0.439 & -0.434 & -0.252 & -0.324 & 0.126 & -0.376 & -0.279 \\
\hline & $\mathrm{Fe}$ & -0.022 & 0.042 & -0.052 & 0.339 & -0.235 & 0.036 & -0.064 & 0.092 & 0.251 & -0.049 & -0.026 & 0.275 \\
\hline & $\mathrm{Ni}$ & $-\mathbf{0 . 8 8 8}^{* *}$ & $-0.876^{* *}$ & $-0.721^{* *}$ & -0.422 & 0.365 & $-0.907^{* *}$ & $-0.899^{* *}$ & $-0.697^{* *}$ & $-0.576^{*}$ & 0.462 & -0.389 & -0.497 \\
\hline & Mo & -0.456 & -0.326 & -0.429 & -0.085 & 0.226 & $-0.515^{*}$ & -0.439 & -0.326 & -0.301 & $0.547^{*}$ & -0.144 & -0.191 \\
\hline & $\mathrm{Pb}$ & 0.306 & 0.348 & 0.321 & 0.389 & -0.285 & 0.23 & 0.282 & 0.38 & 0.355 & -0.176 & 0.182 & 0.354 \\
\hline & V & -0.467 & -0.443 & -0.316 & 0.04 & 0.258 & -0.448 & -0.464 & -0.173 & 0.001 & 0.163 & -0.026 & 0.143 \\
\hline & $\mathrm{Zn}$ & $-0.602^{*}$ & $-0.502^{*}$ & $-0.534^{*}$ & -0.113 & 0.365 & $-0.726^{* *}$ & $-0.591^{*}$ & $-0.664^{* *}$ & -0.287 & 0.421 & 0.024 & -0.251 \\
\hline
\end{tabular}




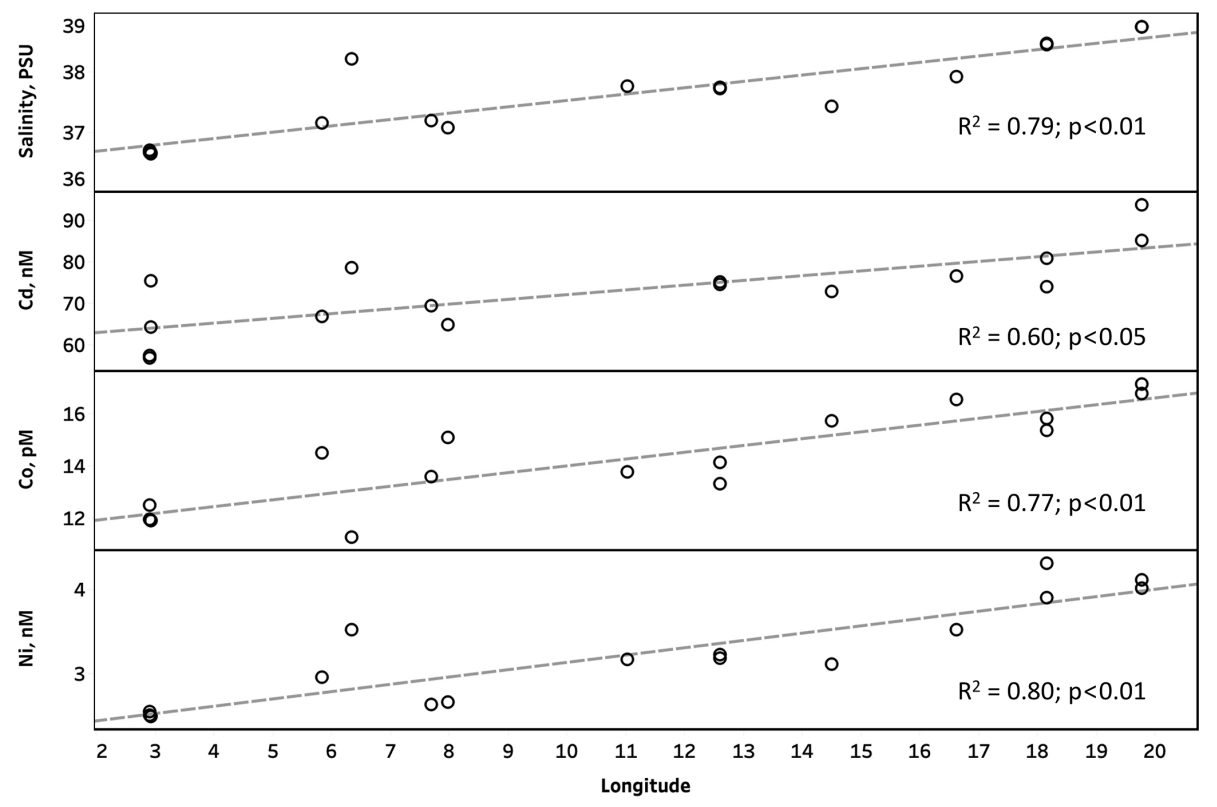

Figure 3. Salinity and concentration of dissolved trace metals in subsurface waters (SSW) plotted against longitude. The dashed lines represent least-square linear regressions.

$0.88 p<0.01$, Table 3), suggesting an influence of the more heavily industrialized northern region of the MS.

D-SSW concentrations of $\mathrm{Ni}$ were strongly and negatively correlated with microbial abundance (mainly with heterotrophic bacteria) in the underlying water $\left(r_{\mathrm{s}}:-0.91, p<\right.$ $0.01 ; R^{2}=0.87, p<0.01$ ) (Fig. 2 and Table 5), which could be interpreted as an indication of a potential negative role of this metal on bacteria and small phytoplankton in the top meter of the western surface of the MS, including the SML. The toxicity of $\mathrm{Ni}$ at concentrations of $\sim 50 \mathrm{nM}$ has been previously demonstrated in the western MS, with inhibitions of $10 \%\left(\mathrm{EC}_{10}\right)$ in phycoerythrin and $\mathrm{Chl} a$ signals of a natural population of the picoplankton Synechococcus sp. (Debelius et al., 2011). Although that toxicity concentration (tested in picoplankton) is around 13 times higher than the average values $( \pm \mathrm{SD})$ measured in our samples (T-SML: $4.1 \pm 0.5 \mathrm{nM}$; D-SML: $3.9 \pm 0.6 \mathrm{nM}$; and D-SSW: $3.2 \pm 0.6 \mathrm{nM}$; see Table 1), deleterious effects on the neuston and microbial communities at lower concentrations might be possible in the top meter of the sea surface. The toxicity to phytoplankton of divalent, cationic trace metals, such as $\mathrm{Ni}$ or $\mathrm{Cu}$, is probably controlled by its free metal ion concentration (Donat et al., 1994). Although the Ni interactions with dissolved organic matter have not been studied well in seawater, they are thought to occur partly as stable organic complexes and with slow dissociation rates (Wen et al., 2011). However, intense UV radiation can alter the concentration, structure, reactivity and metal-binding capacity of the organic matter, thus increasing the proportion of free metal ions and their bioavailability and/or potential toxicity (Cheloni and Slaveykova, 2018). Even if a general decreasing trend in microbial abundance from west to east due to the increasing oligotrophy was observed, it is pertinent to mention that primary production and $\mathrm{Chl} a$ concentration (measured a $5 \mathrm{~m}$ depth) did not show any significant correlations with $\mathrm{Ni}$ (Table 5). It is therefore assumed that the potential toxicity of $\mathrm{Ni}$ would mainly affect the bacterial community in the top meter of the ocean's surface. Nickel, like other transition metals, is an essential cofactor of several enzymes; however, it becomes toxic when homeostasis fails. Multiple potential mechanisms of $\mathrm{Ni}$ toxicity to aquatic organisms, and in particular to bacteria, have been identified (Macomber and Hausinger, 2016). Among the different possible toxicity mechanisms (including the inhibition of $\mathrm{Zn}$ and $\mathrm{Fe}$ metalloenzymes and non-metalloenzymes) the toxicity involving reactive oxygen species (ROS) is probably the highest in surface seawater. While Ni itself is a poor generator of ROS when compared to other metals like $\mathrm{Fe}$ or $\mathrm{Cu}$, its reactivity and ROS production can be enhanced by the displacement of redox-active iron from iron metallocenters (Macomber and Hausinger, 2016) or when chelated by oligopeptides and histidine (Brix et al., 2017), which are abundant in the SML. It appears that nickel-dependent toxicity involving ROS could be a mechanism of oxidative stress in microbial organisms of the surface of oceans.

\section{Conclusions}

Our results show that the SML in the MS is enriched by trace metals relative to the SSW, even under low aerosol deposition rates. Residence times of particulate metals derived from 
aerosol deposition were highly variable, with the largest residence times being for $\mathrm{Cu}(5.8 \pm 6.2 \mathrm{~h})$ and the lowest being for $\mathrm{Fe}(3.6 \pm 6.0 \mathrm{~min})$. A strong negative correlation between the Ni concentration and heterotrophic bacterial abundance in the SML and SSW could be suggestive of an inhibiting role of this element on the microbial growth in the top meter of the surface; however, further research is needed to confirm this finding.

Data availability. Underlying research data are being used by researcher participants of the "Pacetime" campaign to prepare other manuscripts, and therefore data are not publicly accessible at the time of publication. Data will be accessible (http://www.obs-vlfr.fr/ proof/php/PEACETIME/peacetime.php, last access: 28 April 2020) once the special issue is completed (all papers should be published by fall 2020). The policy of the database is detailed here http://www. obs-vlfr.fr/proof/dataconvention.php (last access: 28 April 2020).

Supplement. The supplement related to this article is available online at: https://doi.org/10.5194/bg-17-2349-2020-supplement.

Author contributions. ATS, AE, BZ, FF, EM, MPL, KD, and CG designed the research; ATS, ARR, BZ, FF, MPL, MB, TW, KD, and CG performed the research; ST and GS contributed the analytic tools and analyzed the data; and all coauthors contributed to the writing of the paper.

Competing interests. The authors declare that they have no conflict of interest.

Special issue statement. This article is part of the special issue "Atmospheric deposition in the low-nutrient-low-chlorophyll (LNLC) ocean: effects on marine life today and in the future (ACP/BG interjournal SI)". It is not associated with a conference.

Acknowledgements. This work is a contribution of the project PEACETIME (http://peacetime-project.org, last access: 24 April 2020), a joint initiative of the MERMEX and ChArMEx components supported by CNRS-INSU, IFREMER, CEA, and Météo-France as part of the program MISTRALS coordinated by INSU (https://doi.org/10.17600/17000300). All data were acquired during the PEACETIME oceanographic expedition on board R/V Pourquoi Pas? in May-June 2017. The authors thank Isabel Carribero and Joaquin Pampin for their assistance with the chemical analysis. We thank Julia Uitz, Céline Dimier and the SAPIGH analytical platform at IMEV from HPLC for the sampling and analyses of Chl $a$. The European radar composite products were provided by the Odyssey system, created in the framework of the Opera Program, the radar component of the Eumetnet Observation Program, which is built in parallel at the MetOffice and Meteo France centers. We kindly acknowledge Fabio D'Ortenzio for his help with Odyssey data processing. We thank the crew of the R/V Pourquoi Pas? for technical assistance on the field. Araceli Rodríguez-Romero was supported by the Spanish grant "Juan de la Cierva Formación 2015" (JCI-2015-26873) and "Juan de la Cierva Incorporación 2019" (IJC2018-037545-I). Matthieu Bressac was funded by the European Commission's Seventh Framework Programme (FP7/2007-2013) under grant agreement no. PIOF-GA-2012-626734 (IRON-IC project). We acknowledge support relating to the publication fee from the CSIC Open Access Publication Support Initiative through its Unit of Information Resources for Research (URICI).

Financial support. This research has been supported by the Spanish Ministry of Science, Innovation, and Universities (grant no. CTM2014-59244-C3-3-R), the Spanish grant "Juan de la Cierva Formación 2015" (grant no. JCI-2015-26873) and "Juan de la Cierva Incorporación 2019” (grant no. IJC2018-037545-I), and the European Commission's Seventh Framework Programme (IRON-IC, grant no. 626734).

We acknowledge support relating to the publication fee from the CSIC Open Access Publication Support Initiative through its Unit of Information Resources for Research (URICI).

Review statement. This paper was edited by Christine Klaas and reviewed by three anonymous referees.

\section{References}

Achterberg, E. P., Braungardt, C. B., Sandford, R. C., and Worsfold, P. J.: UV digestion of seawater samples prior to the determination of copper using flow injection with chemiluminescence detection, Anal. Chim. Acta, 440, 27-36, https://doi.org/10.1016/S0003-2670(01)00824-8, 2001.

Agogue, H., Casamayor, E. O., Bourrain, M., Obernosterer, I., Joux, F., Herndl, G. J., and Lebaron, P.: A survey on bacteria inhabiting the sea surface microlayer of coastal ecosystems, FEMS Microbiol. Ecol., 54, 269-280, 2005.

Baker, A. R., Lesworth, T., Adams, C., Jickells, T. D., and Ganzeveld, L.: Estimation of atmospheric nutrient inputs to the Atlantic Ocean from $50^{\circ} \mathrm{N}$ to $50^{\circ} \mathrm{S}$ based on large-scale field sampling: Fixed nitrogen and dry deposition of phosphorus: Atlantic Atmospheric Nutrient Inputs, Global Biogeochem. Cy., 24, GB3006, https://doi.org/10.1029/2009GB003634, 2010.

Becagli, S., Sferlazzo, D. M., Pace, G., di Sarra, A., Bommarito, C., Calzolai, G., Ghedini, C., Lucarelli, F., Meloni, D., Monteleone, F., Severi, M., Traversi, R., and Udisti, R.: Evidence for heavy fuel oil combustion aerosols from chemical analyses at the island of Lampedusa: a possible large role of ships emissions in the Mediterranean, Atmos. Chem. Phys., 12, 3479-3492, https://doi.org/10.5194/acp-12-3479-2012, 2012.

Bonnet, S., Tovar-Sánchez, A., Panzeca, C., Duarte, C. M., OrtegaRetuerta, E., and Sañudo-Wilhelmy, S. A.: Geographical gradients of dissolved Vitamin B12 in the Mediterranean Sea, Front Microbiol., 4, 126, https://doi.org/10.3389/fmicb.2013.00126, 2013. 
Boyd, P. W., Mackie, D. S., and Hunter, K. A.: Aerosol iron deposition to the surface ocean - Modes of iron supply and biological responses, Mar. Chem., 120, 128-143, https://doi.org/10.1016/j.marchem.2009.01.008, 2010.

Boyle, E. A., Chapnick, S. D., Bai, X. X., and Spivack, A.: Trace metal enrichments in the Mediterranean Sea, Earth Planet. Sc. Lett., 74, 405-419, https://doi.org/10.1016/S0012821X(85)80011-X, 1985.

Brix, K. V., Schlekat, C. E., and Garman, E. R.: The mechanisms of nickel toxicity in aquatic environments: An adverse outcome pathway analysis: Adverse outcome pathway for $\mathrm{Ni}$, Environ. Toxicol. Chem., 36, 1128-1137, https://doi.org/10.1002/etc.3706, 2017.

Bruland, K. W., Franks, R. P., Knauer, G. A., and Martin, J. H.: Sampling and analytical methods for the determination of copper, cadmium, zinc, and nickel at the nanogram per liter level in sea water, Anal. Chim. Acta, 105, 233-245, https://doi.org/10.1016/S0003-2670(01)83754-5, 1979.

Byrne, R. H.: Inorganic speciation of dissolved elements in seawater: the influence of $\mathrm{pH}$ on concentration ratios, Geochem. T., 3, 11, https://doi.org/10.1186/1467-4866-3-11, 2002.

Calzolai, G., Nava, S., Lucarelli, F., Chiari, M., Giannoni, M., Becagli, S., Traversi, R., Marconi, M., Frosini, D., Severi, M., Udisti, R., di Sarra, A., Pace, G., Meloni, D., Bommarito, C., Monteleone, F., Anello, F., and Sferlazzo, D. M.: Characterization of $\mathrm{PM}_{10}$ sources in the central Mediterranean, Atmos. Chem. Phys., 15, 13939-13955, https://doi.org/10.5194/acp-1513939-2015, 2015.

Cheloni, G. and Slaveykova, V.: Combined Effects of Trace Metals and Light on Photosynthetic Microorganisms in Aquatic Environment, Environments, 5, 81, https://doi.org/10.3390/environments5070081, 2018.

Croot, P. L. and Heller, M. I.: The Importance of Kinetics and Redox in the Biogeochemical Cycling of Iron in the Surface Ocean, Front. Microbiol., 3, 219, https://doi.org/10.3389/fmicb.2012.00219, 2012.

Cunliffe, M. and Wurl, O.: Guide to best practices to study the ocean's surface, Occasional publications of the Marine Biological Association of the United Kingdom, Plymouth, available at: http://www.scor-int.org/Publications/ SCOR_GuideSeaSurface_2014.pdf (last access: 24 April 2020), 2014.

Cunliffe, M., Engel, A., Frka, S., Gašparović, B., Guitart, C., Murrell, J. C., Salter, M., Stolle, C., Upstill-Goddard, R., and Wurl, O.: Sea surface microlayers: A unified physicochemical and biological perspective of the air-ocean interface, Prog. Oceanogr., 109, 104-116, https://doi.org/10.1016/j.pocean.2012.08.004, 2013.

Debelius, B., Forja, J. M., and Lubián, L. M.: Toxicity of copper, nickel and zinc to Synechococcus populations from the Strait of Gibraltar, J. Marine Syst., 88, 113-119, https://doi.org/10.1016/j.jmarsys.2011.02.009, 2011.

Desboeufs, K., Bon Nguyen, E., Chevaillier, S., Triquet, S., and Dulac, F.: Fluxes and sources of nutrient and trace metal atmospheric deposition in the northwestern Mediterranean, Atmos. Chem. Phys., 18, 14477-14492, https://doi.org/10.5194/acp-1814477-2018, 2018.

Donat, J. R., Lao, K. A., and Bruland, K. W.: Speciation of dissolved copper and nickel in South San Francisco Bay: a multi-method approach, Anal. Chim. Acta, 284, 547-571, https://doi.org/10.1016/0003-2670(94)85061-5, 1994.

Duce, R. A., Liss, P. S., Merrill, J. T., Atlas, E. L., Buat-Menard, P., Hicks, B. B., Miller, J. M., Prospero, J. M., Arimoto, R., Church, T. M., Ellis, W., Galloway, J. N., Hansen, L., Jickells, T. D., Knap, A. H., Reinhardt, K. H., Schneider, B., Soudine, A., Tokos, J. J., Tsunogai, S., Wollast, R., and Zhou, M.: The Atmospheric Input of Trace Species to the World Ocean, Global Biogeochem. Cy., 5, 193-259, 1991.

Dulaquais, G., Planquette, H., L'Helguen, S., Rijkenberg, M. J. A., and Boye, M.: The biogeochemistry of cobalt in the Mediterranean Sea: Cobalt in the Mediterranean Sea, Global Biogeochem. Cy., 31, 377-399, https://doi.org/10.1002/2016GB005478, 2017.

Ebling, A. M. and Landing, W. M.: Sampling and analysis of the sea surface microlayer for dissolved and particulate trace elements, Mar. Chem., 177, 134-142, https://doi.org/10.1016/j.marchem.2015.03.012, 2015.

Ebling, A. M. and Landing, W. M.: Trace elements in the sea surface microlayer: rapid responses to changes in aerosol deposition, Elem. Sci. Anth., 5, p. 42 https://doi.org/10.1525/elementa.237, 2017.

Elbaz-Poulichet, F., Guieu, C., and Morley, N. H.: A Reassessment of Trace Metal Budgets in the Western Mediterranean Sea, Mar. Pollut. Bull., 42, 623-627, https://doi.org/10.1016/S0025326X(01)00065-0, 2001.

Engel, A.: Determination of marine gel particles, in: Practical Guidelines for the Analysis of Seawater, edited by: Wurl, O., 125-142, CRC Press Taylor \& Francis Group, Boca Raton FL, 2009.

Engel, A. and Galgani, L.: The organic sea-surface microlayer in the upwelling region off the coast of Peru and potential implications for air-sea exchange processes, Biogeosciences, 13, 989-1007, https://doi.org/10.5194/bg-13-989-2016, 2016.

Engel, A., Bange, H. W., Cunliffe, M., Burrows, S. M., Friedrichs, G., Galgani, L., Herrmann, H., Hertkorn, N., Johnson, M., Liss, P. S., Quinn, P. K., Schartau, M., Soloviev, A., Stolle, C., Upstill-Goddard, R. C., van Pinxteren, M., and Zäncker, B.: The Ocean's Vital Skin: Toward an Integrated Understanding of the Sea Surface Microlayer, Front. Mar. Sci., 4, 165, https://doi.org/10.3389/fmars.2017.00165, 2017.

Formenti, P., D’Anna, B., Flamant, C., Mallet, M., Piketh, S. J., Schepanski, K., Waquet, F., Auriol, F., Brogniez, G., Burnet, F., Chaboureau, J.-P., Chauvigné, A., Chazette, P., Denjean, C., Desboeufs, K., Doussin, J.-F., Elguindi, N., Feuerstein, S., Gaetani, M., Giorio, C., Klopper, D., Mallet, M. D., Nabat, P., Monod, A., Solmon, F., Namwoonde, A., Chikwililwa, C., Mushi, R., Welton, E. J., and Holben, B.: The Aerosols, Radiation and Clouds in southern Africa (AEROCLO-sA) field campaign in Namibia: overview, illustrative observations and way forward, B. Am. Meteorol. Soc., 100, 1277-1298, https://doi.org/10.1175/BAMS-D17-0278.1, 2019.

Fu, F., Triquet, S., Tovar-Sánchez, A., Bressac, M., Doussin, J.-F., Giorio, C., Siour, G., and Desboeufs, K.: Characterization of wet deposition and its impact on the marine concentration of trace metals during PEACETIME cruise in the Mediterranean Sea, Atmos. Chem. Phys. Discuss., in preparation, 2020.

Guerzoni, S., Molinaroli, E., and Chester, R.: Saharan dust inputs to the western Mediterranean Sea: depositional patterns, geo- 
chemistry and sedimentological implications, Deep-Sea Res. Pt. II, 44, 631-654, https://doi.org/10.1016/S0967-0645(96)000963, 1997.

Guieu, C., Bozec, Y., Blain, S., Ridame, C., Sarthou, G., and Leblond, N.: Impact of high Saharan dust inputs on dissolved iron concentrations in the Mediterranean Sea: Impact of High Saharan Dust Inputs, Geophys. Res. Lett., 29, 17-1-17-4, https://doi.org/10.1029/2001GL014454, 2002.

Guieu, C., Loÿe-Pilot, M.-D., Benyahya, L., and Dufour, A.: Spatial variability of atmospheric fluxes of metals ( $\mathrm{Al}, \mathrm{Fe}, \mathrm{Cd}, \mathrm{Zn}$ and $\mathrm{Pb}$ ) and phosphorus over the whole Mediterranean from a one-year monitoring experiment: Biogeochemical implications, Mar. Chem., 120, 164-178, https://doi.org/10.1016/j.marchem.2009.02.004, 2010.

Guieu, C., D’Ortenzio, F., Dulac, F., Taillandier, V., Doglioli, A., Petrenko, A., Barrillon, S., Mallet, M., Nabat, P., and Desboeufs, K.: Process studies at the air-sea interface after atmospheric deposition in the Mediterranean Sea: objectives and strategy of the PEACETIME oceanographic campaign (May-June 2017), Biogeosciences Discuss., https://doi.org/10.5194/bg-2020-44, in review, 2020.

Hardy, J. T., Apts, C. W., Crecelius, E. A., and Fellingham, G. W.: The sea-surface microlayer: Fate and residence times of atmospheric metals: Surface microlayer metals, Limnol. Oceanogr., 30, 93-101, https://doi.org/10.4319/lo.1985.30.1.0093, 1985.

Harvey, G. W.: Microlayer Collection from the Sea Surface: A New Method and initial Results: Microlayer Collection from the Sea Surface, Limnol. Oceanogr., 11, 608-613, https://doi.org/10.4319/lo.1966.11.4.0608, 1966.

Heimburger, A., Losno, R., and Triquet, S.: Solubility of iron and other trace elements in rainwater collected on the Kerguelen Islands (South Indian Ocean), Biogeosciences, 10, 6617-6628, https://doi.org/10.5194/bg-10-6617-2013, 2013.

Heimbürger, L.-E., Migon, C., Dufour, A., Chiffoleau, J.-F., and Cossa, D.: Trace metal concentrations in the North-western Mediterranean atmospheric aerosol between 1986 and 2008: Seasonal patterns and decadal trends, Sci. Total Environ., 408, 2629-2638, https://doi.org/10.1016/j.scitotenv.2010.02.042, 2010.

Hunter, K. A.: Processes affecting particulate trace metals in the sea surface microlayer, Mar. Chem., 9, 49-70, https://doi.org/10.1016/0304-4203(80)90006-7, 1980.

Jordi, A., Basterretxea, G., Tovar-Sánchez, A., Alastuey, A., and Querol, X.: Copper aerosols inhibit phytoplankton growth in the Mediterranean Sea, P. Natl. Acad. Sci. USA, 109, 21246-21249, https://doi.org/10.1073/pnas.1207567110, 2012.

Joux, F., Agogue, H., Obernosterer, R., Dupuy, C., Reinthaler, T., Herndl, G. J., and Lebaron, P.: Microbial community structure in the sea surface microlayer at two contrasting coastal sites in the northwestern Mediterranean Sea, Aquat. Microb. Ecol., 14, 91-104, 2006.

Macomber, L. and Hausinger, R. P.: Nickel Toxicity, Regulation, and Resistance in Bacteria, in: Stress and Environmental Regulation of Gene Expression and Adaptation in Bacteria, edited by: de Bruijn, F. J., 1131-1144, John Wiley \& Sons, Inc., Hoboken, NJ, USA, 2016.

Marañón, E., Holligan, P. M., Varela, M., Mouriño, B., and Bale, A. J.: Basin-scale variability of phytoplankton biomass, production and growth in the Atlantic Ocean, Deep-Sea Res. Pt. I, 47, 825857, https://doi.org/10.1016/S0967-0637(99)00087-4, 2000.

Marie, D., Partensky, F., Jacquet, S., and Vaulot, D.: Enumeration and Cell Cycle Analysis of Natural Populations of Marine Picoplankton by Flow Cytometry Using the Nucleic Acid Stain SYBR Green I, Appl. Environ. Microb., 63, 186-193, 1997.

Migon, C.: Trace Metals in the Mediterranean Sea, in: The Mediterranean Sea, edited by: Saliot, A., 151-176, Springer Berlin Heidelberg, https://doi.org/10.1007/b107146, 2005.

Milne, A., Landing, W., Bizimis, M., and Morton, P.: Determination of $\mathrm{Mn}, \mathrm{Fe}, \mathrm{Co}, \mathrm{Ni}, \mathrm{Cu}, \mathrm{Zn}, \mathrm{Cd}$ and $\mathrm{Pb}$ in seawater using high resolution magnetic sector inductively coupled mass spectrometry (HR-ICP-MS), Anal. Chim. Acta, 665, 200-207, https://doi.org/10.1016/j.aca.2010.03.027, 2010.

Moffett, W. and Zika, G.: Mesurement of copper(I) in surface waters of the subtropical Atlantic and Gulf of Mexico, Geochim. Cosmochim. Ac., 52, 1849-1857, https://doi.org/10.1016/00167037(88)90008-7, 1988.

Nicolas, E., Ruiz-Pino, D., Buat-Ménard, P., and Bethoux, J. P.: Abrupt decrease of lead concentration in the Mediterranean sea: A response to antipollution policy, Geophys. Res. Lett., 21, 2119-2122, https://doi.org/10.1029/94GL01277, 1994.

Obernosterer, I., Catala, P., Reinthaler, T., Herndl, G., and Lebaron, P.: Enhanced heterotrophic activity in the surface microlayer of the Mediterranean Sea, Aquat. Microb. Ecol., 39, 293-302, https://doi.org/10.3354/ame039293, 2005.

Obernosterer, I., Catala, P., Lami, R., Caparros, J., Ras, J., Bricaud, A., Dupuy, C., van Wambeke, F., and Lebaron, P.: Biochemical characteristics and bacterial community structure of the sea surface microlayer in the South Pacific Ocean, Biogeosciences, 5, 693-705, https://doi.org/10.5194/bg-5-693-2008, 2008.

Passow, U.: Transparent exopolymer particles (TEP) in aquatic environments, Prog. Oceanogr., 55, 287-333, https://doi.org/10.1016/S0079-6611(02)00138-6, 2002.

Paytan, A., Mackey, K. R. M., Chen, Y., Lima, I. D., Doney, S. C., Mahowald, N., Labiosa, R., and Post, A. F.: Toxicity of atmospheric aerosols on marine phytoplankton, P. Natl. Acad. Sci. USA, 106, 4601-4605, https://doi.org/10.1073/pnas.0811486106, 2009.

Pey, J., Querol, X., Alastuey, A., Forastiere, F., and Stafoggia, M.: African dust outbreaks over the Mediterranean Basin during 2001-2011: $\mathrm{PM}_{10}$ concentrations, phenomenology and trends, and its relation with synoptic and mesoscale meteorology, Atmos. Chem. Phys., 13, 1395-1410, https://doi.org/10.5194/acp13-1395-2013, 2013.

Pulido-Villena, E., Ghiglione, J. F., Ortega-Retuerta, E., VanWambeke, F., and Zohary, T.: Heterotrophic bacteria in the pelagic realm of the Mediterranean Sea, in Life in the Mediterranean Sea: a look at habitat changes, 227-266, Nova Publishers, New York, 2012.

Rajot, J. L., Formenti, P., Alfaro, S., Desboeufs, K., Chevaillier, S., Chatenet, B., Gaudichet, A., Journet, E., Marticorena, B., Triquet, S., Maman, A., Mouget, N., and Zakou, A.: AMMA dust experiment: An overview of measurements performed during the dry season special observation period (SOP0) at the Banizoumbou (Niger) supersite, J. Geophys. Res., 113, D00C14, https://doi.org/10.1029/2008JD009906, 2008.

Ras, J., Claustre, H., and Uitz, J.: Spatial variability of phytoplankton pigment distributions in the Subtropical South Pacific Ocean: 
comparison between in situ and predicted data, Biogeosciences, 5, 353-369, https://doi.org/10.5194/bg-5-353-2008, 2008.

Sarthou, G. and Jeandel, C.: Seasonal variations of iron concentrations in the Ligurian Sea and iron budget in the Western Mediterranean Sea, Mar. Chem., 74, 115-129, https://doi.org/10.1016/S0304-4203(00)00119-5, 2001.

Sherrell, R. M. and Boyle, E. A.: Zinc, chromium, vanadium and iron in the Mediterranean Sea, Deep-Sea Res. Pt. A, 35, 13191334, https://doi.org/10.1016/0198-0149(88)90085-4, 1988.

Stortini, A. M., Cincinelli, A., Degli Innocenti, N., Tovar-Sánchez, A., and Knulst, J.: 1.12 - Surface Microlayer, in: Comprehensive Sampling and Sample Preparation, edited by: Pawliszyn, J., 223-246, Academic Press, Oxford, available at: http://www. sciencedirect.com/science/article/pii/B9780123813732000181 (last access: 24 April 2020), 2012.

Sunda, W. G.: Feedback Interactions between Trace Metal Nutrients and Phytoplankton in the Ocean, Front Microbiol., 3, 204, https://doi.org/10.3389/fmicb.2012.00204, 2012.

Ternon, E., Guieu, C., Loÿe-Pilot, M.-D., Leblond, N., Bosc, E., Gasser, B., Miquel, J.-C., and Martín, J.: The impact of Saharan dust on the particulate export in the water column of the North Western Mediterranean Sea, Biogeosciences, 7, 809-826, https://doi.org/10.5194/bg-7-809-2010, 2010.

Tovar-Sánchez, A., Serón, J., Marbà, N., Arrieta, J. M., and Duarte, C. M.: Long-term records of trace metal content of western Mediterranean seagrass (Posidonia oceanica) meadows: Natural and anthropogenic contributions, J. Geophys. Res., 115, G02006, https://doi.org/10.1029/2009JG001076, 2010.

Tovar-Sánchez, A., Arrieta, J. M., Duarte, C. M., and SañudoWilhelmy, S. A.: Spatial gradients in trace metal concentrations in the surface microlayer of the Mediterranean Sea, Front. Mar. Sci., 1, 79, https://doi.org/10.3389/fmars.2014.00079, 2014.
Tovar-Sánchez, A., González-Ortegón, E., and Duarte, C. M.: Trace metal partitioning in the top meter of the ocean, Sci. Total Environ., 652, 907-914, https://doi.org/10.1016/j.scitotenv.2018.10.315, 2019.

Trezzi, G., Garcia-Orellana, J., Rodellas, V., SantosEcheandia, J., Tovar-Sánchez, A., Garcia-Solsona, E., and Masqué, P.: Submarine groundwater discharge: A significant source of dissolved trace metals to the North Western Mediterranean Sea, Mar. Chem., 186, 90-100, https://doi.org/10.1016/j.marchem.2016.08.004, 2016.

Wen, L.-S., Santschi, P. H., Warnken, K. W., Davison, W., Zhang, H., Li, H.-P., and Jiann, K.-T.: Molecular weight and chemical reactivity of dissolved trace metals $(\mathrm{Cd}$, $\mathrm{Cu}, \mathrm{Ni}$ ) in surface waters from the Mississippi River to Gulf of Mexico, Estuarine, Coast. Shelf Sci., 92, 649-658, https://doi.org/10.1016/j.ecss.2011.03.009, 2011.

Wurl, O.: Practical Guidelines for the Analysis of Seawater, 1st Edn., CRC Press, Florida, 2009.

Wurl, O., Ekau, W., Landing, W. M., and Zappa, C. J.: Sea surface microlayer in a changing ocean - A perspective, Elem. Sci. Anth., 5, 31, https://doi.org/10.1525/elementa.228, 2017.

Yoon, Y.-Y., Martin, J.-M., and Cotté, M. H.: Dissolved trace metals in the Western Mediterranean Sea: total concentration and fraction isolated by C18 Sep-Pak technique, Mar. Chem., 66, 129148, https://doi.org/10.1016/S0304-4203(99)00033-X, 1999.

Zäncker, B., Cunliffe, M., and Engel, A.: Bacterial Community Composition in the Sea Surface Microlayer Off the Peruvian Coast, Front. Microbiol., 9, 2699, https://doi.org/10.3389/fmicb.2018.02699, 2018. 